دراسة إقتصادية لأهم المشاكل والمعوقات التى تواجه مزارعى الفلقل بالصوب الزراعية بمحافظة الدقهلية فى ظل فيرس كورونا المستجد

\author{
د.رشا صالح منصور \\ د. .محمود معوض محمد
}

باحث أول- معهد بحوث الإقتصاد الزراعى

المستخلص

تعتبر مشاريع الصوب الزراعية وخاصة النى تقوم بإنتاج وزراعة محاصيل الخضر من أكثر المشاريع التى تحقق أرباحاً غير عادية ،

حيث تؤدى نلك المشاريع إلى سد الفجوه بين العرض والطلب من نلك المحاصيل فى الأسواق المحلية، إضافة إلى زيادة دخل المزارعين من خلال زراعة محاصيل عالية القيمة تحقق مكاسب مرتفعة مما يؤدى لرفع مسنوى معيثة المزارعين ، وتوفير فرص عمل لثباب الخريجين ، كما يمكن لئن

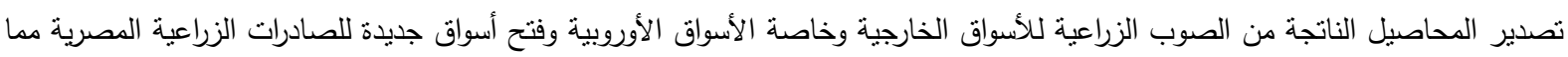

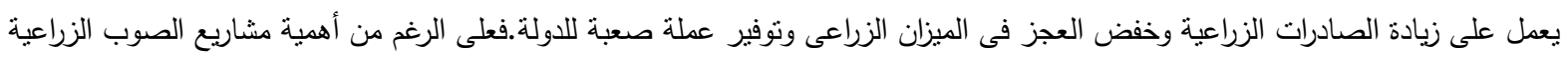

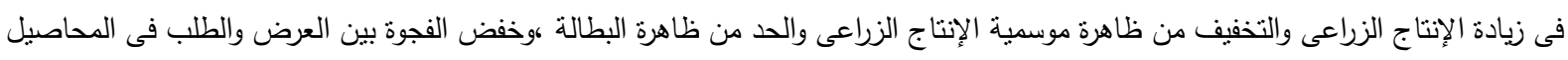

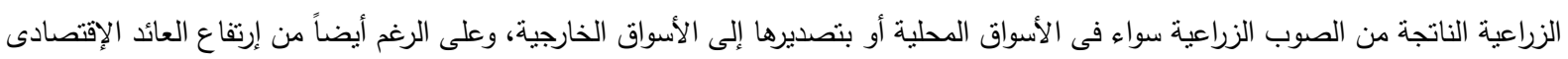

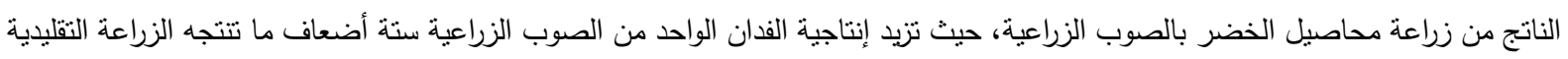

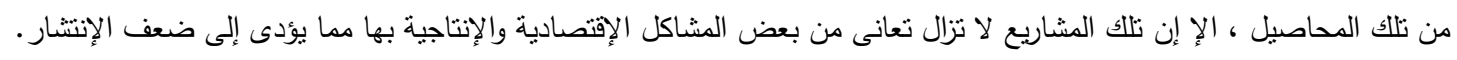
وقد إعتد هذا البحث على إسلوب التحليل الإحصائى الوصفى ، كما تم إستخدام معامل ألفا كرونباخ لقياس صدق وثبات العينة البحثية

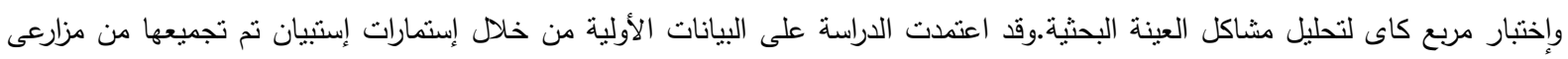
محاصيل الدراسة بمحافظة الدقهلية من خلال إجراء المقابلات الميدانية للمزارعين. كما إعتمدت الدراسة على البيانات الثانوية المنشورة في الموقع العانع الإكترونى لقطاع الثئون الإقتصادية بوزارة الزراعى ونشرات الإدارة المركزية للاقتصاد الزراعى ، كما تم الإستعانة ببعض الأبحاث والرسائل

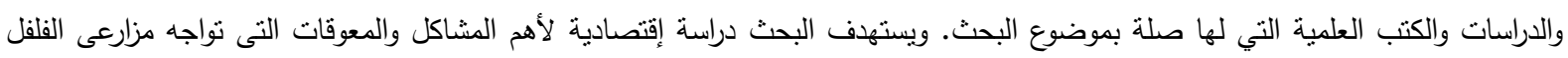
بالصوب الزراعية بمحافظة الدقهلية فى ظل فيرس كورونا المستجد من خلال : (1) التعرف على أهم المشاكل والمعوقات التى تواجه مزارعى الفلفل

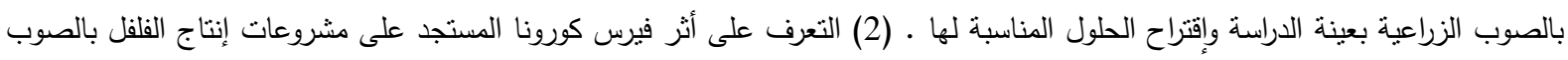

الزراعية بعينة الدراسة.(3) دراسة أهم العوامل المؤثرة على فيرس كورونا المستجد على مشروع الصوب الزراعية لمحصول الفلفل بعينة الدراسة.

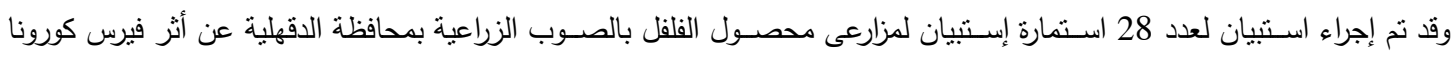

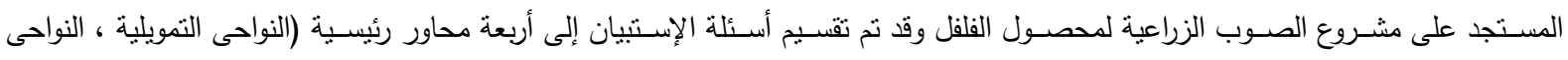

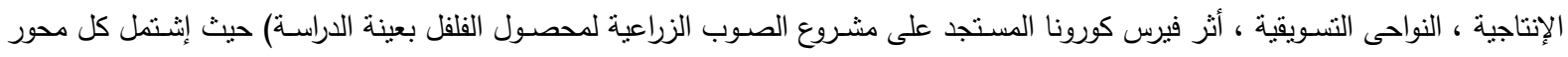

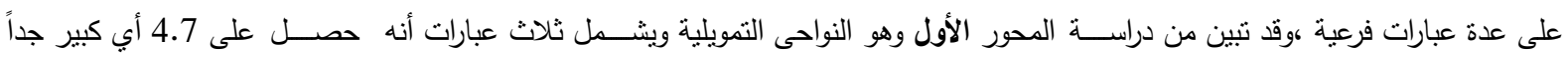

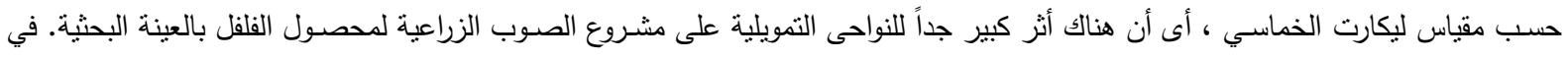

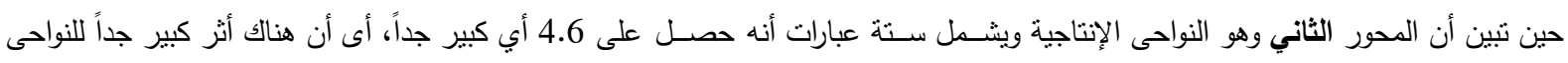

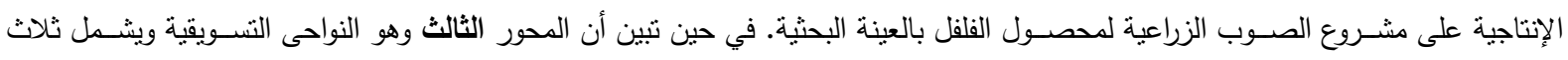

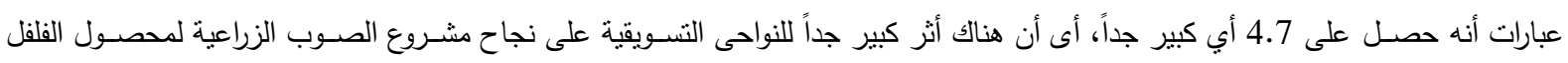

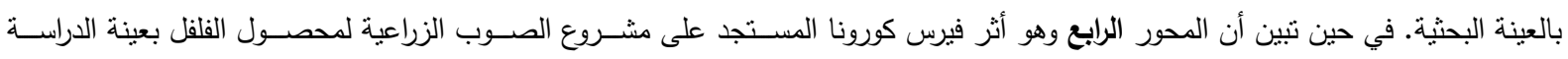
ويثمل ستة عبارات أنه حصل على 4.2 أي كبير جداً ، أى أن هناك أثر لفيرس كورونا المستجد على مشروع الصوب السئ الزراعية لمحصول الفلفل 
فى حين تيين من دراسة أهم العوامل المؤثرة على أثر فيرس كورونا المستجد على مشروع زراعة محصول الفلفل بالصوب الزراعية بمحافظة الدقهلية أن تلك العوامل هي المشاكل التمويلية ، المشاكل التسويقية حيث تمنل متغيرات هامة في التأثثر على أثر فيرس كورونا المستجد على مشروع زراعة محصول الفلفل بالصوب الزراعية ، لذلك يوصى الباحث بالإهنمام بحل المشاكل التمويلية ، المشاكل التسويقية لتأثيرها على مشروع زراعة

محصول الفلفل بالصوب الزراعية بالعينة البحثية بمحافظة الدقهلية. وقد تبين أن أهم المقترحات من وجهة نظر مزارعى الصوب الزراعية لمحصول الفلفل بالعينة البحثية بمحافظة الدقهلية أهم تللك المقترحات

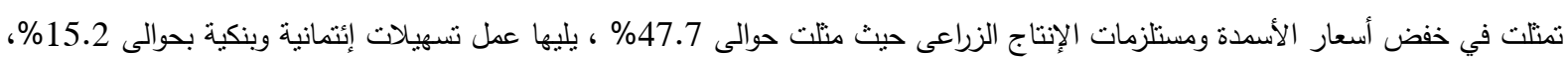
يليها خفض أسعار التقاوى ونشر التقاوى المحسنة مرتفعة الإنتاجية بحوالى 12.1\%، يليها زيادة دور الإرشاد بالتعريف بأهمية المشروعات الصغيرة وخاصة الصوب الزراعية بحوالى 10.6\% ، يليها تنهيل معرفة المزارع بالفرص التصديرية للأسواق الخارجية بحوالى 7.6\% ، ثم خفض أسعار مستلزمات الصوب بحوالى 6.8\%.

مقدمة:

تعتبر مشكلة نقص الغذاء وتحقيق الإكتفاء الذاتى للسـلع الغذائية من أهم المشـاكل الرئيسية التى يعانى منها الإقتصـاد المصـرى ، لعدم قدرته على توفير الغذاء بالقدر الكافى مما يحدث خلالاً فى الفجوة الغذائية بين العرض والطلب وحدوث مشـــكلة الأمن الغذائى ، وبذلك فإن الأمر ينطلب تضـافر الجهود لوضـع الخطط الإقتصـادية والزراعية بهدف زيادة الإنتاج الزراعى لأقصى قدر ممكن من ناحية وترشبيد الإستهلاك الغذائى من ناحية أخرى ، وزيادة الطاقة التصديرية للسلع ذات الميزه التتافسية كأحد مقومات الأمن الغذائى للتغلب على زيادة الواردات لسلع الأمن الغذائى. وقد يتطلب الأمر تصــحيح الخلل في القطاع الزراعي المصـري وإحداث بعض التعديلات الهيكلية في السـياسـات الزراعية أو سـياسـات التجارة الخارجية الزراعية والسـياسـات المالية الزراعية ، بالإضـافة إلى إجراء تعديلات في دور بنك التتمية والائتمان الزراعي ، وتتـجيع القطاع الخاص

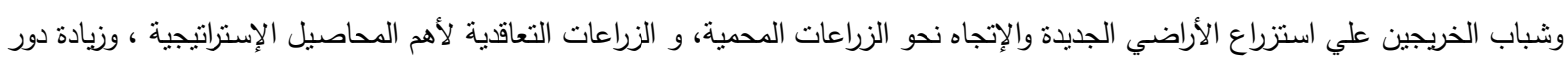
القطاع الخاص في تجارة وتوزيع مســتلزمات الإنتاج الزراعي ، وإتخاذ بعض التســـهيلات فى الإجراءات البنكية ، وإزالة العوائق أمام المســتـمر

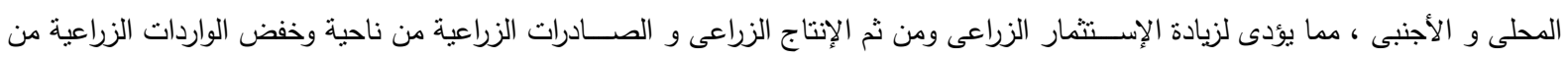
ناحية أخرى ومن ثم خفض العز فى الميزان التجارى الكلى والزراعى المصرى.

المشكلة البحثية:

تعتبر مشاريع الصوب الزراعية وخاصة التى تقوم بزراعة محاصيل الخضر من أكثر المشاريع التى تحقق أرباحاً غير عادية ، حيث تؤدى تللك المشاريع إلى سد الفجوه بين العرض والطلب من تلك المحاصيل فى الأسواق المحلية، إضافة إلى زبادة دخل المزارعين من خلال زراعة محاصيل عالية القيمة تحقق مكاسب مرتفعة مما يؤدى لرفع مستوى معيشة المزارعين ، وتوفير فرص عمل لشباب الخريجين ، كما يمكن تصدير المحاصيل الناتجة من الصوب الزراعبة للأسواق الخارجية وخاصة الأسواق الأوروبية وفتح أسواق جديدة للصادرات الزراعبة المصرية مما بعمل ئل على زيادة الصادرات الزراعية وخفض العجز فى الميزان الزراعى وتوفير عملة صعبة للدولة. فعلى الرغم من أهمية مشاريع الصوب الزراعية فى زيادة الإنتاج الزراعى والتخفيف من ظاهرة موسمية الإنتاج الزراعبوالحد من ظاهرة البطالة ،وخفض الفجوة بين العرض والطلب فى المحاصيل الزراعية الناتجة من الصوب الزراعية سواء فى الأسواق المحلية أو بتصديرها إلى الأسواق الخارجية، وعلى الرغم أيضاً من إرتفاع العائد الإقتصادى لرئ الناتج من زراعة محاصيل الخضر بالصوب الزراعية، حيث تزيد إنتاجية الفدان الواحد من الصوب الزراعية ستة أضعاف ما نتتجه الزراعة التقليدية من تلاك المحاصيل ، الإ إن تلك المشاريع لا نزال تعانى من بعض المشاكل الإقتصادية والإنتاجية والتسويقية بها مما يؤدى إلى ضعف إنتشار تلك

$$
\text { المشاريع على المستوى المحلى. }
$$


الأهداف البحثية:

يستهدف البحث دراسة أهم المشاكل والمعوقات التى نواجه مزارعى الفلفل بالصوب الزراعية بمحافظة الدقهلية فى ظل فيرس كورونا

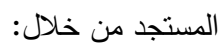

1.التعرف على أثر فيرس كورونا المستجد على مشروعات إنتاج الفلفل بالصوب الزراعية بعينة الدراسة.

2.دراسة أهم العوامل المؤثرة على فيرس كورونا المستجد على مشروع الصوب الزراعية لمحصول الفلفل بعينة الدراسة. 3.التعرف على أهم المشاكل والمعوقات التى تواجه مزارعى الفلفل بالصوب الزراعية بعينة الدراسة وإقتراح الحلول المناسبة لها.

الإسلوب البحثي ومصادر البيانات:

إعتمدت هذا البحث على إسلوب التحليل الإحصائى الوصفى ، كما نم إستخدام معامل ألفا كرونباخ لقياس صدق وثبات العينة البحثية

وإختبار مربع كاى لتحليل مشاكل العينة البحثية.وقد اعتمدت الدراسة على البيانات الأولية من خلال إستمارات إسنيبان تم تجميعها من مزارعى محاصيل الدراسة بمحافظة الدقهلية من خلا إجراء المقابلات الميدانية للمزارعين. كما إعتمدت الدراسة على البيانات الثانوية المنشورة في الموقع الإكترونى لقطاع الثئون الإقتصادية بوزارة الزراعى ونشرات الإدارة المركزية للاقتصاد الزراعى ، كما نم الإستعانة ببعض الأبحاث والرسائل والدراسات والكتب العلمية التي لها صلة بموضوع البحث.

مناقثة النتائج تم إجراء استبيان لعدد 28 استمارة إستبيان لمزارعى الصوب الزراعية بمحصول الفلفل بمحافظة الدقهلية عن أثر فيرس كورونا المستجد على مشروع الصوب الزراعية لمحصول الفلفوقد تبين من خلال نتائج العينة البحثية بالنسبة:

أولاً: الخصائص الديموجرافية لمزارعى الصوب الزراعية بمحصول القلفل بعينة الدراسة :

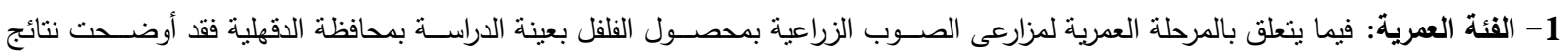

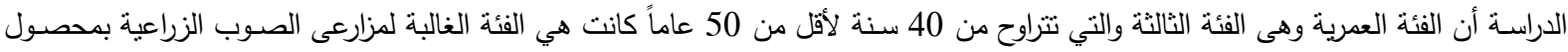
الفلفل بعينة الدراسة حيث بلغت نسبتها حوالي 71\% ، ، ويأتي بعد ذلك مزارعى الصوب الزراعية بمحصول الفلفل بعينة الدراسة في المرحلة العمرية

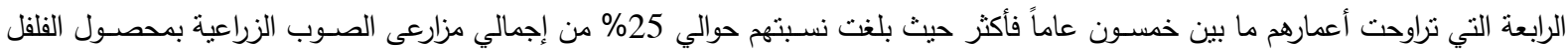

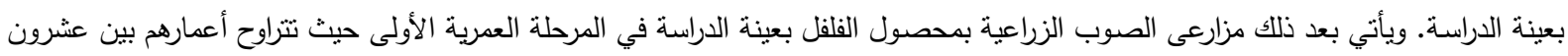

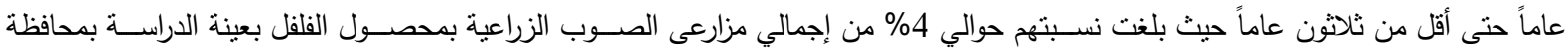

الدقهلية- جدول (1).

2- الحالة الإجتماعية: أوضــت بيانات الدراسـة أن الحالة الإجتماعية متزوج كانت هى الفئة الغالبة لمزارعى الصــوب الزراعية بمحصـول الفلفل

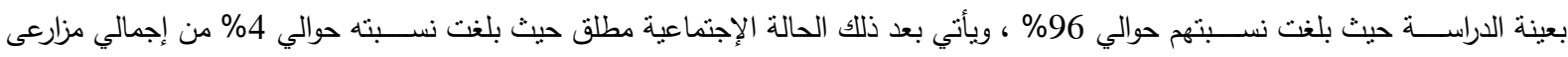
الصوب الزراعية بمحصول الفلفل بعينة الدراسة - جدول (1). 3- المسـتوى التعليمى: أوضـحت بيانات الدراسـة أن المستوى التعليمى المتوسط كان هو الفئة الغالبة لمزارعى الصـوب الزراعية بمحصـول الفلفل

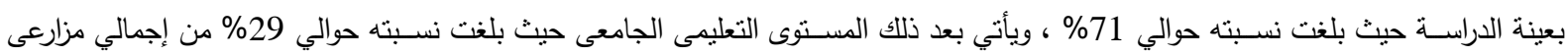
الصوب الزراعية بمحصول الفلفل بعينة الدراسة بمحافظة الدقهلية- جدول (1). ولعل الإثارة إلى قيم الوسط الحسابي المرجح للفئة العمرية لمزارعى الصوب الزراعية بمحصول الفلفل بعينة الدراسة يعطينا صورة أكثر وضوحاً وشمولاً عند تفسير البيانات، حيث بلغ الوسط الحسابي المرجح حوالي 3 بوزن نسبى مرجح بلغ حوالي 0.79 ، أب أنها تقع في الفئة الثالثة والتي تتراوح ما بين (40 سنة- أقل من 50)، حيث تعتبر تلكك الفترة مناسبة للإلمام بكافة الأنشطة الزراعية بما يكفل درجة من الإتقان في الأعمال المسندة لهم ، حيث تتتاسب درجة الإتقان طردياً مع الفئة العمرية.كما بلغ الوسط الحسابي المرجح حوالي 2 بوزن نسبى مرجح بلغ حوالي 0.51 ، أب أنها تقع في الفئة الثانية وهى متزوج. فى حين بلغ الوسط الحسابي المرجح للمؤهل التعليمى لمزارعى الصوب الزراعية بمحصول الفلفل بعينة

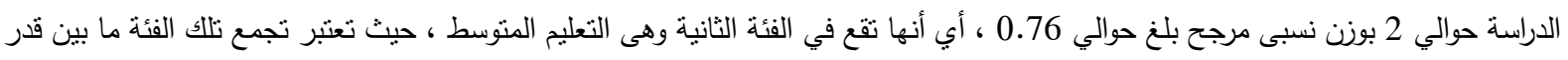

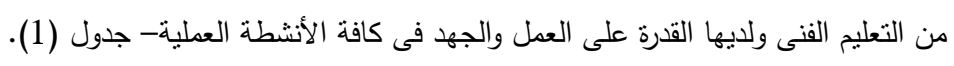


جدول رقم 1. النتائج المرتبطة بخصائص مزارعى الصوب الزراعية بمحصول القلقل بعينة الدراسة

\begin{tabular}{|c|c|c|c|c|c|}
\hline الترتيب & النسبة & المجموع & المتغيرات & الرمز & الخصائص \\
\hline 3 & $\% 4$ & 1 & $30-20$ & 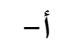 & \multirow{4}{*}{ الفئة العمرية } \\
\hline- & - & - & $40-30$ & ب & \\
\hline 1 & $\% 71$ & 20 & $50-40$ & ج- & \\
\hline 2 & $\% 25$ & 7 & 50- فأكثر & لد- & \\
\hline- & $\% 100$ & 28 & المجمــوع & & \multirow{5}{*}{ الحالة الإجتماعية } \\
\hline- & - & - & أعزب & أ- أ - ا & \\
\hline 1 & $\% 96$ & 27 & متزوج & ب- & \\
\hline 2 & $\% 4$ & 1 & مطلق & ج- & \\
\hline & - & - & 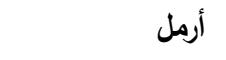 & - د & \\
\hline- & $\% 100$ & 28 & المجمــوع & & \multirow{5}{*}{ المستوى التعليمى } \\
\hline- & - & - & أمى & أ- أ - ا & \\
\hline 1 & $\% 71$ & 20 & تعليم متوسط & ب & \\
\hline 2 & $\% 29$ & 8 & مؤهل عالى & ج- & \\
\hline- & $\% 100$ & 28 & المجموع & & \\
\hline
\end{tabular}

المصدر: جمعت وحسبت من بيانات استمارات الإستبيان.

4- اختبار وجود علاقة بين متغيرات الدراسة الوصفية بمشروع الصوب الزراعية لمحصول الفلفل بعينة الدراسة:

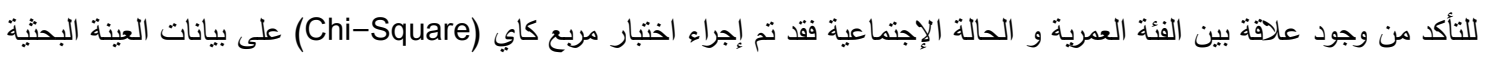
حيث تبين من ننائج جدول (2) أن قيمة مربع كاي قد بلغت حوالي (28.0) بدرجات حرية 2، كما تبين أن أقل قيمة لمستوى الدلالة قد بلغ حوالي

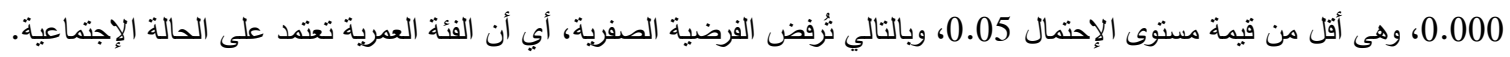
وللنأكد من وجود علاقة بين الفئة العمرية والمستوى التعليمى فقد تم إجراء اختبار مربع كاي على بيانات العينة البحثية حيث تبين من نتائج

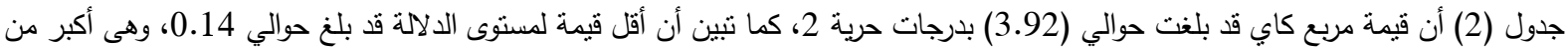

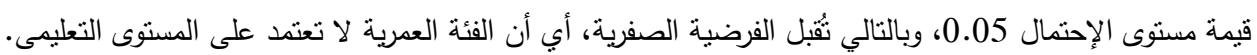
وللتأكد من وجود علاقة بين الحالة الإجتماعية والمستوى التعليمى فقد تم إجراء اختبار مربع كاي على بيانات العينة البحثية حيث تبين من

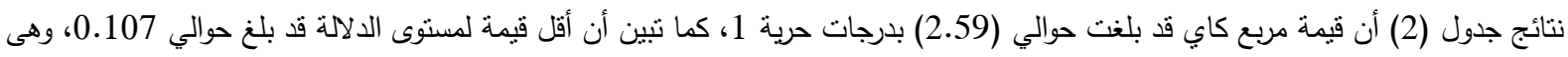
أكبر من قيمة مستوى الإحتمال 0.05، وبالتالي تُقبل الفرضية الصفرية، أي أن الحالة الإجتماعية لا تعتمد على المستوى التعليمى.

جدول رقم 2. نتائج اختبار مريع كاي للتأكد من وجود علاقة بين متغيرات الدراسة الوصفية

\begin{tabular}{|c|c|c|}
\hline 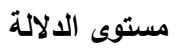 & قيمة مريع كاي & المتغيرات \\
\hline 0.000 & 28.0 & الفئة العمرية X الحالة الإجتماعية \\
\hline 0.141 & 3.92 & الفئة العمرية X المستوى التعليمى \\
\hline 0.107 & 2.59 & الحالة الإجتماعية X المستوى التعليمى \\
\hline
\end{tabular}

المصدر : جمعت وحسبت من بيانات إستمارات الإستبيان بعينة الدراسة.

صدق و ثبات القيم التقديرية لإستمارة استبيان لوصف أثر فيرس كورونا المستجد على مشروع الصوب الزراعية لمحصول القلفل

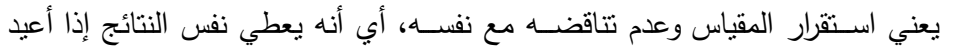

معامل الثبات Reliability Coefficient: مندو ونات

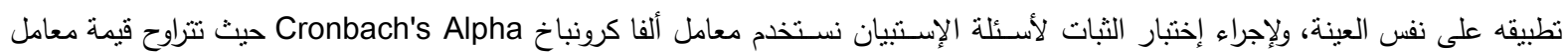
الثبات بين الصفر والواحد الصـحيح، فإذا كانت قيمة معامل الثبات مسـاوية للصفر فلا يكن هناك ثبات في البيانات، وعلى العكس إذا كانت قيمة 
المعامل تسـاوي الواحد الصـحيح فيكن هناك ثبات تام، وكلما اقتربت قيمة معامل الثبات من الواحد فيكون الثبات مرتفعاً وكلما اقتربت قيمته من الصفر فيكون الثبات منخفضاً. معامل الصـدق Validity: ويقصـد به أن المقياس يقيس ما وضـع لقياسـه، حيث يعكس معامل الصـدق الجذر التربيعي لمعامل الثبات، أب أن زيادة قيمة معامل الثبات ألفا كرونباخ تعني زيادة مصداقية بيانات العينة. وقد نبين من نتائج جدول (3) أن معامل الثبات الداخلي (ألفا كرونباخ) قد بلغ حوالي 0.67 وهو مرتفع وموجب التبانه الإشارة مما يعني زيادة مصداقية بيانات العينة البحثية، في حين بلغ معامل الصدق الذاتي حوالي 0.819 وهو أيضاً مرتفع مما يشير إلى صدق بيانات العينة البحثية. ويتضح من الجدول السابق أن معظم معاملات المتغيرات تتمتع بدرجة عالية من الثبات، وبذلك يمكن الإعنماد على نتائجها فى الدراسة البحثية.

جدول رقم 3. النتائج المرنبطة بمعامل الصدق والثبات لمحاور قياس أثز فيرس كورونا المستجد على مشروع الصوب الزراعية لمحصول الفلفل

\begin{tabular}{|c|c|c|}
\hline & & بالعينة البحثية \\
\hline معامل الصدق الذاتي & معامل الثبات الاخلي (ألفا-كرونباخ) & 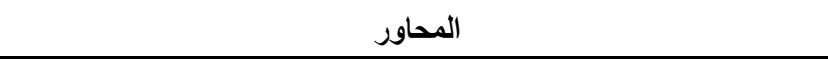 \\
\hline 0.748 & 0.560 & أثر المشاكل التمويلية على مشروع الصوب الزراعية لمحصول القلفل \\
\hline 0.879 & 0.773 & أثثر المشاكل الإنتاجية على مشروع الصوب الزراعية لمحصول الفلفل \\
\hline 0.617 & 0.381 & أثر المشاكل التسويقية على مشروع الصوب الزراعية لمحصول القلقل \\
\hline 0.943 & 0.889 & أثث فيرس كورونا المستجد على مشروع الصوب الزراعية لمحصول الفلقل \\
\hline 0.819 & 0.670 & 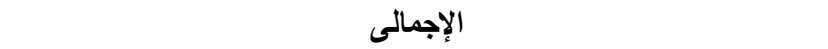 \\
\hline
\end{tabular}

المصدر : جمعت وحسبث من بيانات استمارة الإستبيان.

وقد نم تقسيم إجابات عبارات المحاور على أساس مقياس ليكارت الخماسي، حيث أن المتغير يعبر عن خمسة عن خيارات (كبير جداً=5، كبير =4، منوسط=3، صغير=2، ليس له دور =1) ثم نحسب بعد ذللك المنتسط الحسابي (المنتوط المرجح). حيث يتم ذلك بحساب طول الفترة أولاً وهي عبارة عن حاصل قسمة عدد المسافات على عدد الاختبارات، (حيث أن عدد المسافات هي أربعة مسافات- المسافة الأولى من 1 إلى 2، دئل المسافة الثانية من 2 إلى 3، المسافة الثالثة من 3 إلى 4، المسافة الرابعة من 4 إلى 5)، في حين أن عدد الاختيارات هي خمسة اختيارات، فيكون الناتج هو طول الفترة ويساوي 0.80، حيث يصبح التوزيع كما يوضح جدول (4).

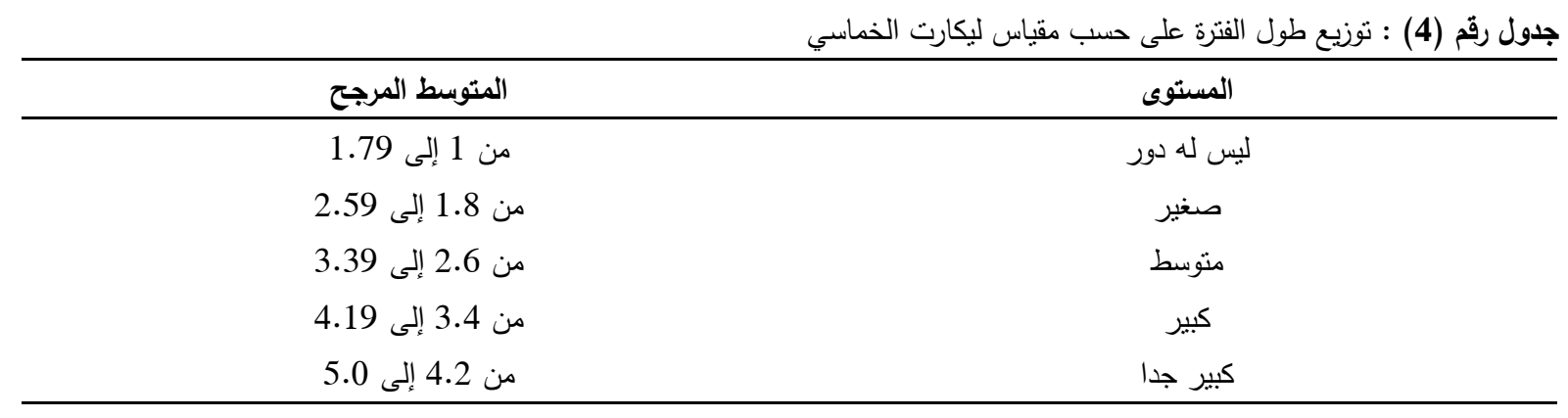

المصدر: حسبت من توزيع عبارات الإسنبيان.

ثانياً : تحليل وتفسير نتائج الدراسة الميدانية المرتبطة بأثر فيرس كورونا المستجد على مشروع الصوب الزراعية لمحصول الفلفل لدراسة بأثر فيرس كورونا المستجد على مشروع الصوب الزراعية لمحصول القلقل بعينة الدراسة بمحافظة الدقهلية فقد تم تقسيم أسئلة الإستبيان إلى أربعة محاور رئيسية وهى: المحور الأول: دور النواحى التمويلية على مشروع الصوب الزئه ولئه الزراعية لمحصول الفلفل بعينة الدراسة. المحور الثانى: دور النواحى الإنتاجية على مشروع الصوب الزراعية لمحصول الفلفل بعينة الدراسة. المحور الثالث: دور النواحى التسويقية على مشروع الصوب الزراعية لمحصول الفلفل بعينة الدراسة. المحور الرابع: بأثر فيرس كورونا المستجد على مشروع الصوب الزراعية لمحصول الفلفل بعينة الدراسة.

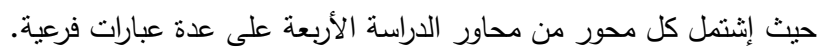


المحور الأول : دور النواحى التمويلية على مشروع الصوب الزراعية لمحصول الفلقل بعينة الدراسة بمحافظة الدقهلية يضم المحور الأول دور النواحى التمويلية على مشروع الصوب الزراعية لمحصول الفلفل بعينة الدراسة بمحافظة الدقهلية حيث إثنمل

$$
\begin{aligned}
& \text { على ثلاث عبارات فرعية هى : }
\end{aligned}
$$

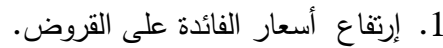

$$
\begin{aligned}
& \text { 2. عدم وجود تسهيلات إئتمانية بنكية للحصول على القروض القروض. } \\
& \text { 3. ضعف قيمة القروض التمويلية. } \\
& \text { وفيما يلى تفصيل لعبارات ذلك المحور : }
\end{aligned}
$$

تنين من خلال نتائج جدول (5) والذى يتعلق بأثر النواحى التمويلية على مشروع الصوب الزراعية لمحصول الفلفل بعينة الدراسة بمحافظة

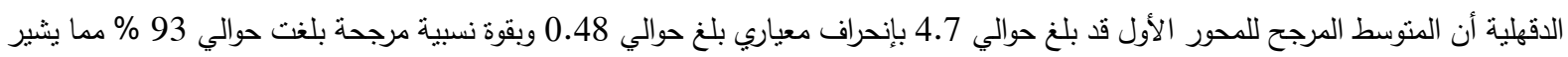

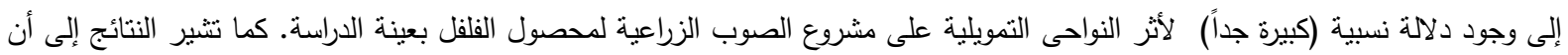

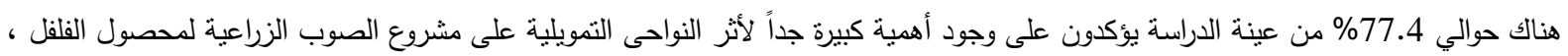

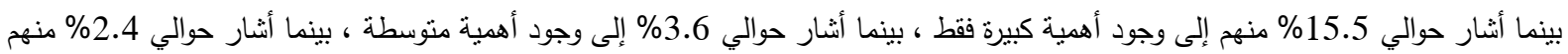
إلى وجود أهمية صغيرة ، بينما أثنار حوالي 1.2\% إلى عدم وجود ألى أهمية لأثر النواحى التمويلية على مشروع الصوب الزراعية لمحصول الفلفل. وفى ضوء نتائج جدول (5) وبترتيب عبارات المحور الأول نرتيباً تنازلياً طبقاً للمتوسط المرجح والقوة النسبية المرجحة لكل عبارة من عبارات

المحور تبين أن:

الترتيب الأول: جاءت عبارة إرتفاع أسعار الفائدة على القروض بمتوسط مرجح بلغ حوالي 4.8 ، ووزن نسبى مرجح بلغ حوالي 0.96، وبإنحراف معياري بلغ حوالي 0.69، وقد جاءت إجابات المبحوثين بالترتيب أن حوالي 89\% أثناروا إلى وجود أهمية كبيرة جداً لأثر إرتفاع أسعار

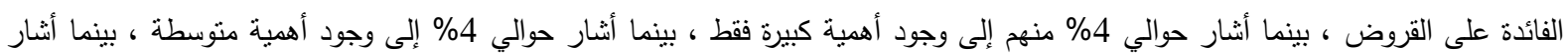

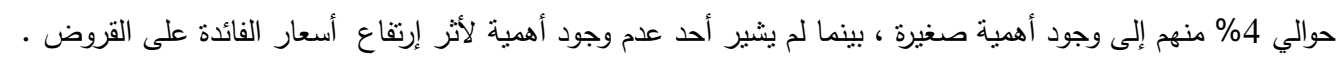
الترتيب الثاني: جاءت عبارة ضعف قيمة القروض التمويلية بمنوسط مرجح بلغ حوالي 4.5 ، ووزن نسبى مرجح بلغ حوالي 0.91،

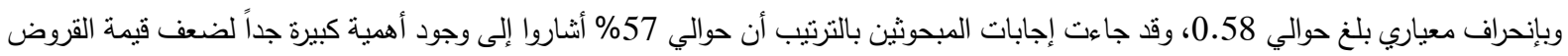

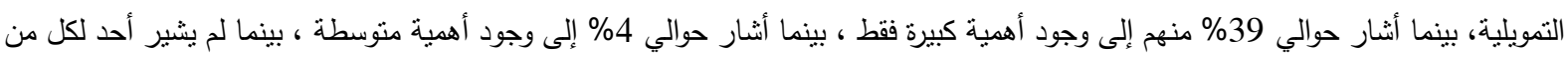

\begin{tabular}{|c|c|c|c|c|c|c|c|c|c|c|c|}
\hline ب الترتي & النتيجة & المرجحة & الانعراف & المتوس & ليس له & 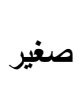 & متوبط & 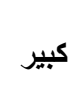 & كبير & & 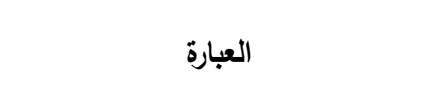 \\
\hline \multirow{2}{*}{1} & كبير - اير & \multirow{2}{*}{0.96} & \multirow{2}{*}{0.69} & \multirow{2}{*}{4.8} & $\mathbf{0}$ & 1 & 1 & 1 & 25 & 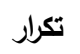 & 1-إرتفاع أسعار الفائدة على \\
\hline & جداً & & & & $\mathbf{0}$ & 4 & 4 & 4 & 89 & $\%$ & القروض \\
\hline \multirow{2}{*}{3} & كبير & \multirow{2}{*}{0.93} & \multirow{2}{*}{0.99} & \multirow{2}{*}{4.6} & 1 & 1 & 1 & 1 & 24 & 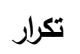 & 2-عدم وجود تسهيلات إئتمانية بنكية \\
\hline & جداً & & & & 4 & 4 & 4 & 4 & 86 & $\%$ & للحصول على القروض \\
\hline \multirow{2}{*}{2} & 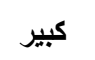 & \multirow{2}{*}{0.91} & \multirow{2}{*}{0.58} & \multirow{2}{*}{4.5} & $\mathbf{0}$ & $\mathbf{0}$ & 1 & 11 & 16 & 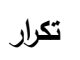 & \multirow{2}{*}{ 3-ضعف قيمة القروض التمويلية } \\
\hline & جداً & & & & $\mathbf{0}$ & $\mathbf{0}$ & 4 & 39 & 57 & $\%$ & \\
\hline- & كبيرً & 0.93 & 0.48 & 4.7 & 1 & 2 & 3 & 13 & 65 & 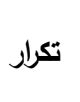 & 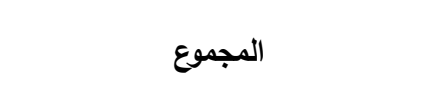 \\
\hline- & - & - & - & - & 1.2 & 2.4 & 3.6 & 15.5 & 77.4 & $\%$ & النسبة المئوية \\
\hline
\end{tabular}

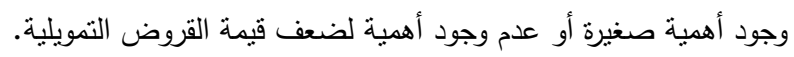

جدول رقم 5. دور النواحى التمويلية على مشروع الصوب الزراعية لمحصول الفلفل بعينة الدراسة بمحافظة الدقهلية

المصدر : جمعت وحسبت من استمارات الاسنتيان.

الترتيب الثالث: جاءت عبارة عدم وجود نسهيلات إئتمانية بنكية للحصول على القروض بمنوسط مرجح بلغ حوالي 4.6 ، ووزن نسبى

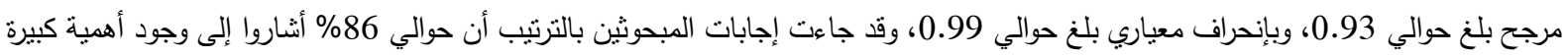

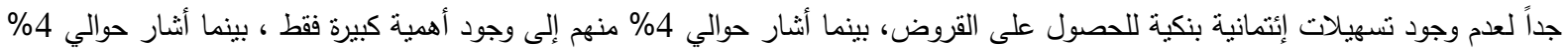


إلى وجود أهمية متوسطة ، بينما أثنار حوالي 4\% منهم إلى وجود أهمية صغيرة ، بينما أثنار حوالي 4\% لعدم وجود أهية لعدم وجود تسهيلات إنتمانية بنكية للحصول على القروض.

المحور الثانى : دور النواحى الإنتاجية على مشروع الصوب الزراعية لمحصول الفلفل بعينة الدراسة بمحافظة الدقهلية

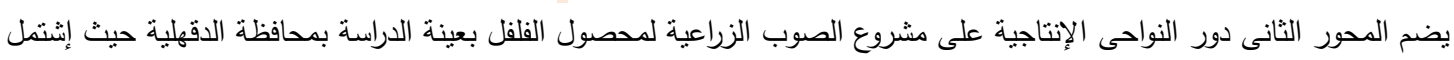

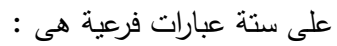
1. إرتفاع أسعار الأسمدة الكيماوية. 2. إرتفاع أسعار المبيدات الزراعية. 3. إرتفاع تكاليف إنثاء الصوب الزراعية. 4. إنخفاض الخبرة فى مجال الصوب الزراعية

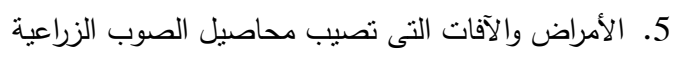
6. إرتفاع أجور الأيدى العاملة

وفيما يلى تفصيل لعبارات ذلك الدحور :

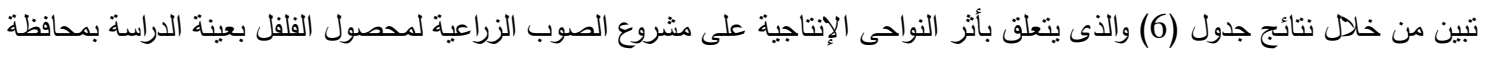
الدقلية أن المتوسط المرجح للمحور الثانى قد بلغ حوالي 4.6 بإنحراف معياري بلغ حوالي

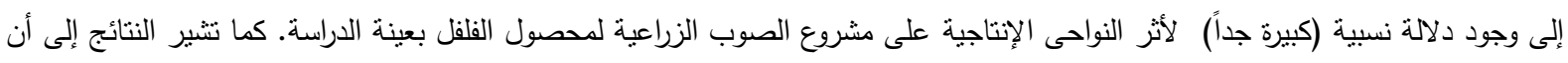

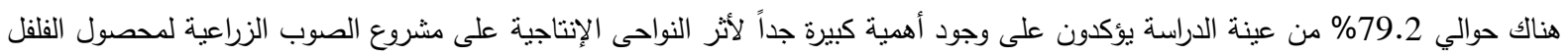

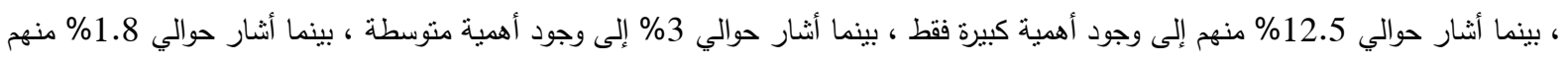

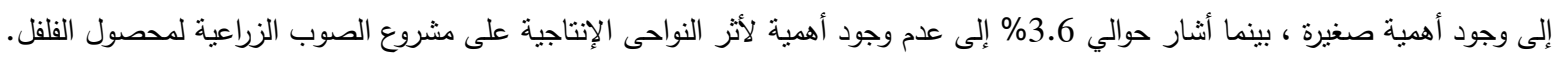

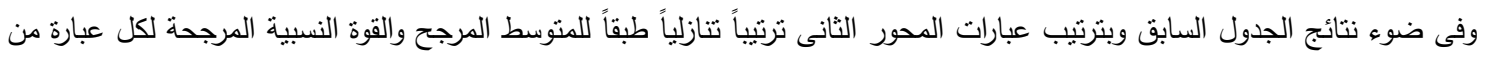

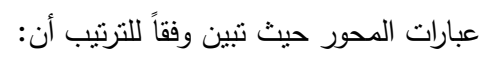

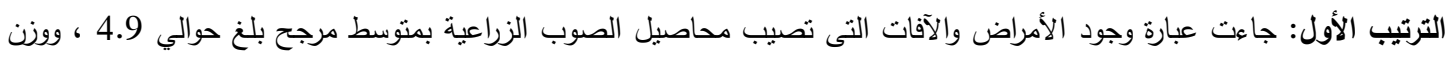

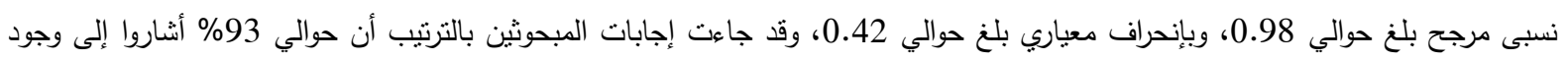

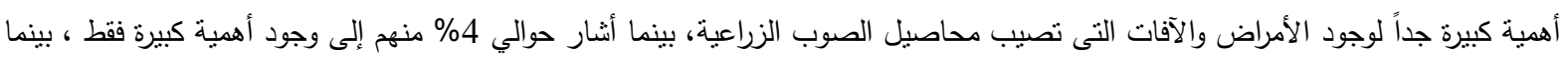

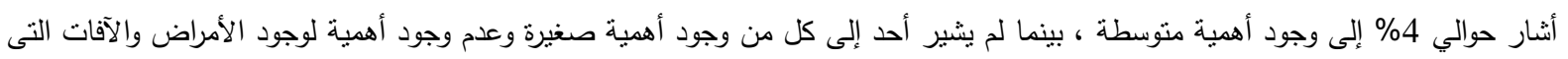

تصيب محاصيل الصوب الزراعية.

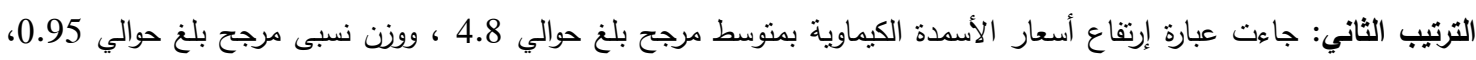

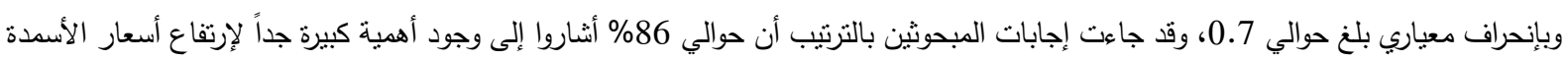

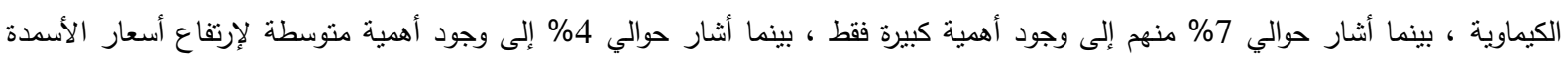

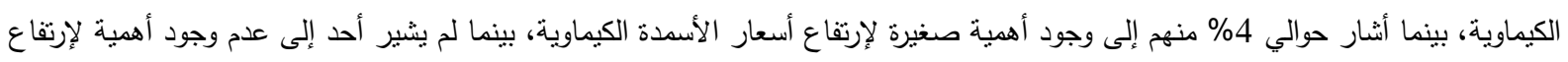
أسعار الأسمدة الكيماوية.

الترتيب الثالث: جاءت عبارة إرتفاع تكاليف إنشاء الصوب الزراعية بمتوسط مرجح بلغ حوالي 4.6 ، و ووزن نسبى مرجح بلغ حوالي

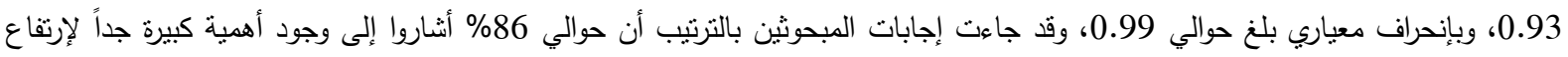

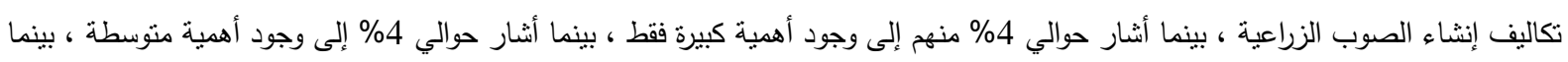

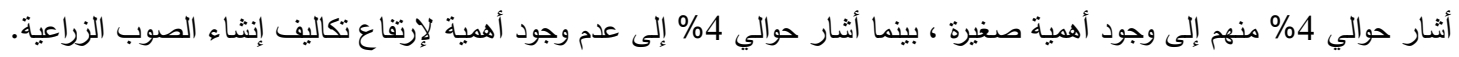

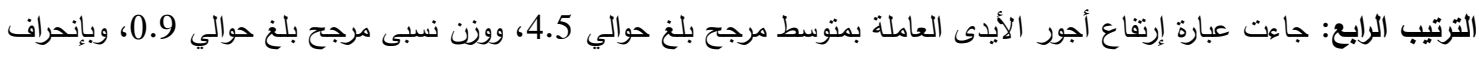

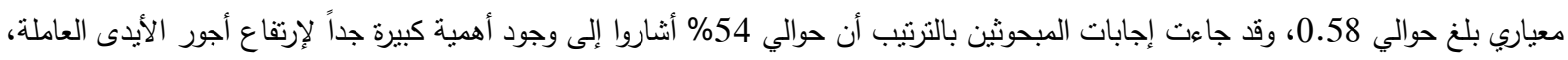

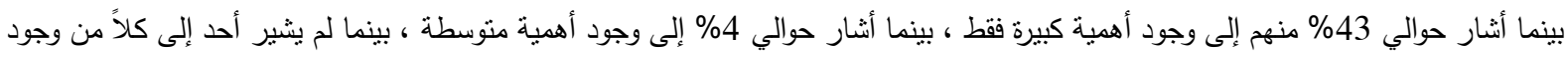
أهمية صغيرة وعدم وجود أهمية لإرتفاع أجور الأيدى العاملة.

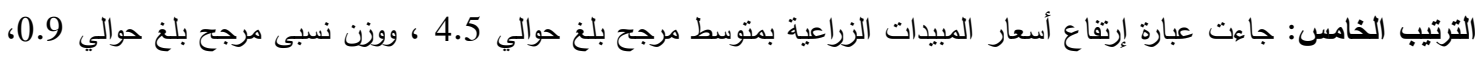
وبإنحراف معياري بلغ حوالي 1.2، وقد جاءت إجابات المبحوثين بالتزتيب أن حوالي 82\% أثناروا إلى وجود أهمية كبيرة جداً لإرتفاع أسعار المبيدات 
الزراعية، بينما أثنار حوالي 4\% منهم إلى وجود أهمية كبيرة فقط ، بينما أثشار حوالي 4\% إلى وجود أهمية متوسطة ، بينما أثنار حوالي 4\% منهم إلى وجود أهمية صغيرة ، بينما أشار حوالي 4\% بـ إلى عدم وجود أهمية لإرتفاع أسعار المبيدات الزراعية.

الترتيب السادس: جاءت عبارة إنخفاض الخبرة فى مجال الصوب الزراعية بمتوسط مرجح بلغ حوالي 4.4 ، ووزن نسبى مرجح بلغ حوالي

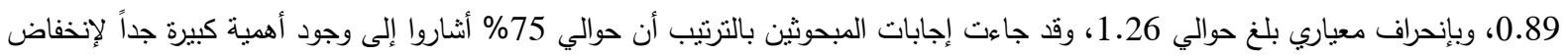

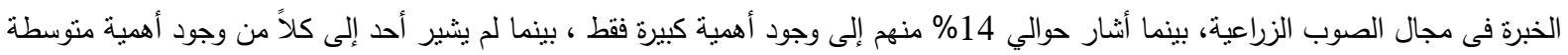
ووجود أهمية صغيرة ، بينما أثنار حوالي 11\% إلى عدم وجود أهمية لإنخفاض الخبرة فى مجال الصوب الزراعية.

جدول رقم 6. دور النواحى الإنتاجية على مشروع الصوب الزراعية لمحصول الفلفل بعينة الدراسة بمحافظة الدقهلية

\begin{tabular}{|c|c|c|c|c|c|c|c|c|c|c|c|}
\hline الترتي & النتيجة & المرجبة & 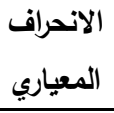 & المتوس & ليس له & 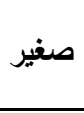 & متوسط & كبيز & جبيز & & 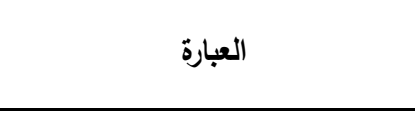 \\
\hline \multirow{2}{*}{2} & كبير & \multirow{2}{*}{0.95} & \multirow{2}{*}{0.70} & \multirow{2}{*}{4.8} & $\mathbf{0}$ & 1 & 1 & 2 & 24 & 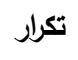 & \multirow{2}{*}{ 1-إرتفاع أسعار الأسمدة الكيماوية } \\
\hline & جداً & & & & $\mathbf{0}$ & 4 & 4 & 7 & 86 & $\%$ & \\
\hline \multirow{2}{*}{5} & 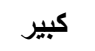 & \multirow{2}{*}{0.90} & \multirow{2}{*}{1.20} & \multirow{2}{*}{4.5} & 2 & 1 & 1 & 1 & 23 & 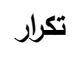 & \multirow{2}{*}{ 2-إرتفاع أسعار المبيدات الزراعية } \\
\hline & جداً & & & & 4 & 4 & 4 & 4 & 82 & $\%$ & \\
\hline \multirow{2}{*}{3} & كبير & \multirow{2}{*}{0.93} & \multirow{2}{*}{0.99} & \multirow{2}{*}{4.6} & 1 & 1 & 1 & 1 & 24 & 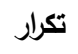 & \multirow{2}{*}{ 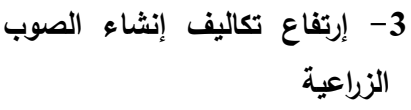 } \\
\hline & جداً & & & & 4 & 4 & 4 & 4 & 86 & $\%$ & \\
\hline \multirow{2}{*}{6} & كبيز & \multirow{2}{*}{0.89} & \multirow{2}{*}{1.26} & \multirow{2}{*}{4.4} & 3 & $\mathbf{0}$ & $\mathbf{0}$ & 4 & 21 & 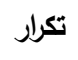 & \multirow{2}{*}{ 4-إنخفاض الخبرة فى مجال الصوب } \\
\hline & 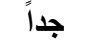 & & & & 11 & $\mathbf{0}$ & $\mathbf{0}$ & 14 & 75 & $\%$ & \\
\hline \multirow{2}{*}{1} & كبيز & \multirow{2}{*}{0.98} & \multirow{2}{*}{0.42} & \multirow{2}{*}{4.9} & $\mathbf{0}$ & $\mathbf{0}$ & 1 & 1 & 26 & تكرار & \multirow{2}{*}{ 5-الأمراض والآقات التى تصيب } \\
\hline & جداً & & & & $\mathbf{0}$ & $\mathbf{0}$ & 4 & 4 & 93 & $\%$ & \\
\hline \multirow{4}{*}{4} & كبير & \multirow{2}{*}{0.90} & \multirow{2}{*}{0.58} & \multirow{2}{*}{4.5} & $\mathbf{0}$ & $\mathbf{0}$ & 1 & 12 & 15 & تكرار & \multirow{2}{*}{ 6-إرتفاع أجور الأيدى العاملة } \\
\hline & جداً & & & & $\mathbf{0}$ & $\mathbf{0}$ & 4 & 43 & 54 & $\%$ & \\
\hline & كبير & \multirow[t]{2}{*}{0.92} & \multirow[t]{2}{*}{0.46} & \multirow[t]{2}{*}{4.6} & 6 & 3 & 5 & 21 & 133 & تكرار & المجموع \\
\hline & & & & & 3.6 & 1.8 & 3 & 12.5 & 79.2 & $\%$ & النسبة المئوية \\
\hline
\end{tabular}

المصدر : جمعت وحسبث من استمارات الاسنبيان.

المحور الثالث : دور النواحى التسويقية على مشروع الصوب الزراعية لمحصول الفلقل بعينة الدراسة بمحافظة الدقهلية يضم المحور الثالث دور النواحى التسويقية على مشروع الصوب الزراعية لمحصول الفلفل بعينة الدراسة بمحافظة الدقهلية حيث إثنمل

$$
\begin{aligned}
& \text { على أربعة عبارات فرعية هى : } \\
& \text { 1. تذبذب أسعار المحاصيل المنتجة. } \\
& \text { 2. إستغلال تجار الجملة لمنتجى الصوب الزراعية. } \\
& \text { 3. بعد أماكن الإنتاج عن أماكن التسويق. }
\end{aligned}
$$

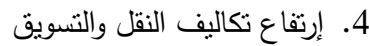

$$
\begin{aligned}
& \text { وفيما يلى تفصيل لعبارات ذلك المحور : }
\end{aligned}
$$

تنين من خلال نتائج جدول (7) والذى يتعلق بأثر النواحى التسويقية على مشروع الصوب الزراعية لمحصول الفلفل بعينة الدراسة بمحافظة

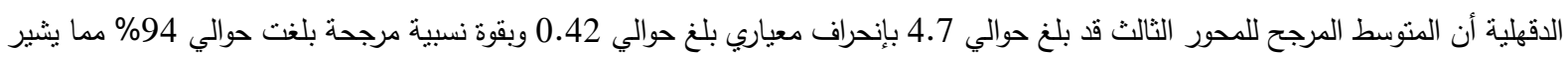
إلى وجود دلالة نسبية (كبيرة جداً) لأثر النواحى التسويقية على مشروع الصوب الزراعية لمحصول الفلفل بعينة الدراسة. كما نتير النتائج إلى أن هناك حوالي 84.8\% من عينة الدراسة يؤكدون على وجود أهمية كبيرة جداً لأثر النواحى التسويقية على مشروع الصوب الزئل الزراعية لمحصول الفلفل

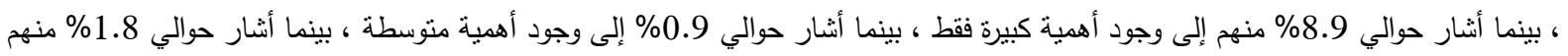
إلى وجود أهمية صغيرة ، بينما أشثار حوالي 3.6\% إلى عدم وجود أهمية لأثر النواحى التسويقية على مشروع الصوب الزراعية لمحصول الفلفل. 
وفى ضوء نتائج الجدول السابق وبترتيب عبارات المحور الثالث ترتيباً نتازلياً طبقاً للمتوسط المرجح والقوة النسبية المرجحة لكل عبارة من

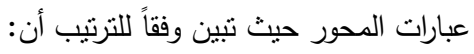
الترتيب الأول: جاءت عبارة بعد أماكن الإنتاج عن أماكن التسويق بمنوسط مرجح بلغ حوالي 4.9 ، ووزن نسبى مرجح بلغ حوالي 0.97،

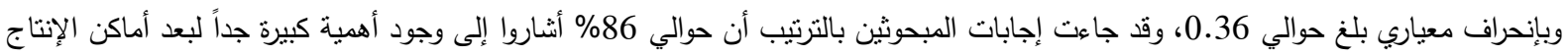

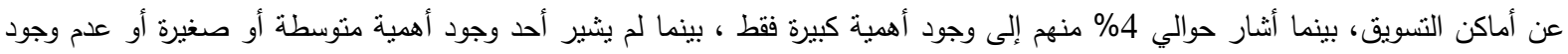
أهمية لبعد أماكن الإنتاج عن أماكن التشويق.

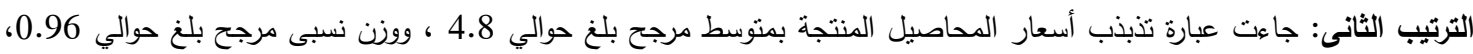

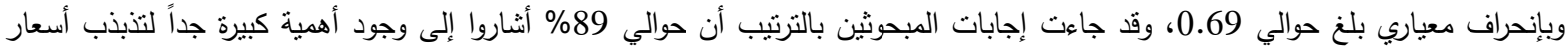

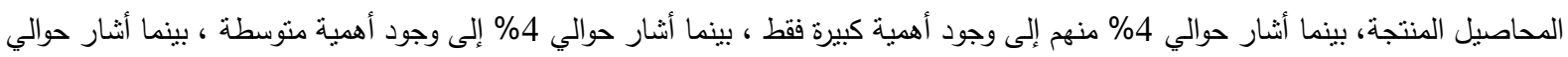
4 منهم إلى وجود أهمية صغيرة ، بينما لم يثير أحد إلى عدم وجود أهمية لتنبذب أسعار المحاصيل المنتجة.

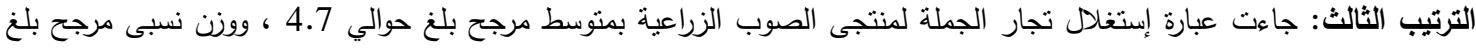

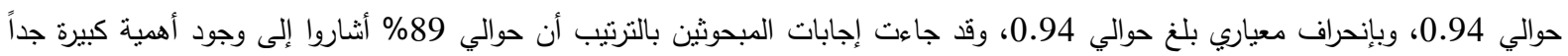

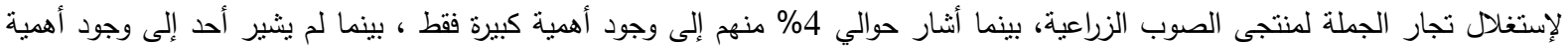

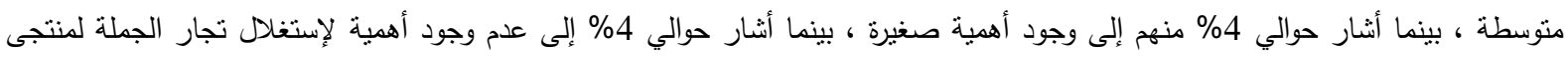
الصوب الزراعية.

الترتيب الرابع: جاءت عبارة إرتفاع تكاليف النقل والتسويق بمنوسط مرجح بلغ حوالي 4.4 ، ووزن نسبى مرجح بلغ حوالي 0.89، التباتي

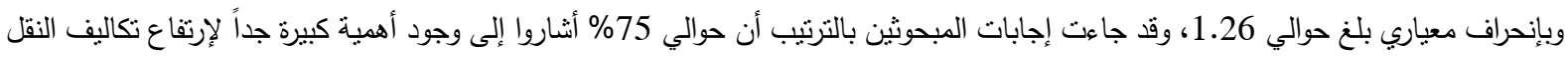

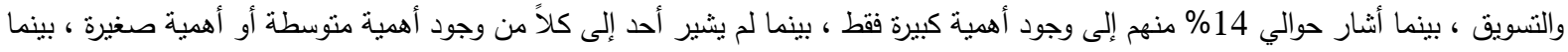
أثنار حوالي 11\% إلى عدم وجود أهمية لإرتفاع نكاليف النقل والنسويق.

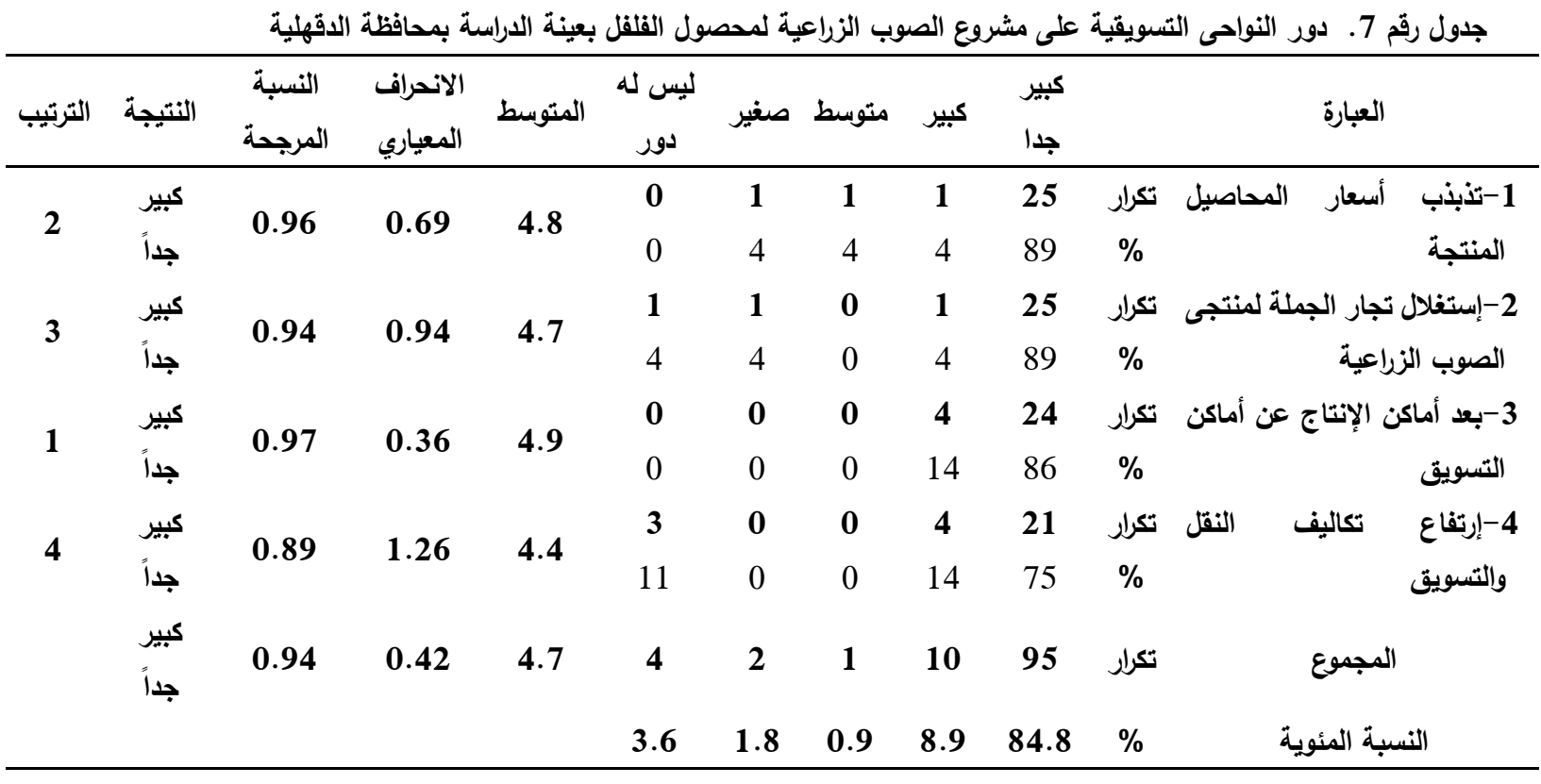

المصدر : جمعت وحسبت من استمارات الاسنبيان.

المحور الرابع : أثر فيرس كورونا المستجد على مثروع الصوب الزراعية لمحصول الفلقل بعينة الاراسة بمحافظة الدقهلية

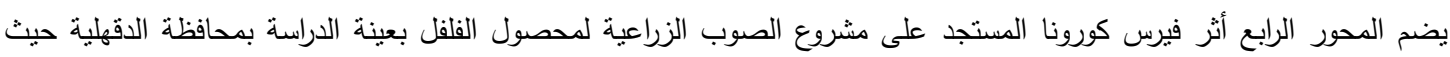
إثتنل على ستة عبارات فرعية هى : 1. الأثر على إنتاج الصوب الزراعية.

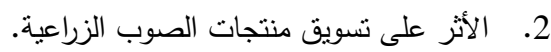




$$
\begin{aligned}
& \text { 3. الأثر على هامش الربح. } \\
& \text { 4. الأثر على أسعار محاصيل الصوب الزراعية } \\
& \text { 5. الأثر على توفر العمالة الزراعية الددربة } \\
& \text { 6. الأثر على تصدير محاصيل الصوب الزراعية } \\
& \text { وفيما يلى تفصيل لعبارات ذلك المحور: }
\end{aligned}
$$

تيين من خلال نتائج جدول (8) والذى يتعلق بأثر فيرس كورونا المستجد على مشروع الصوب الزراعية لمحصول الفلفل بعينة الدراسة

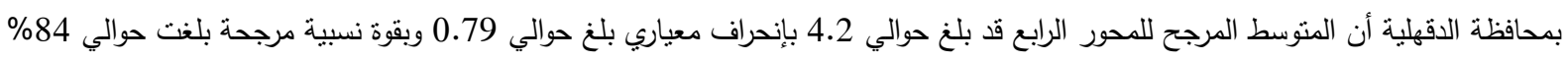

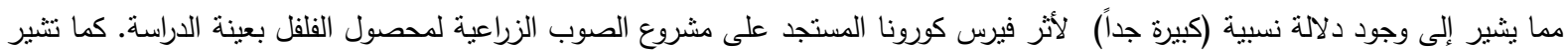

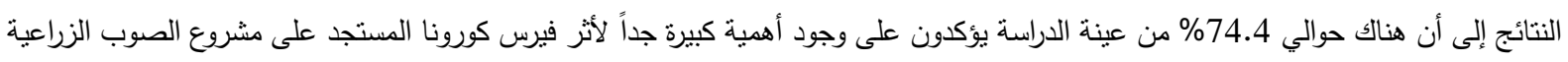

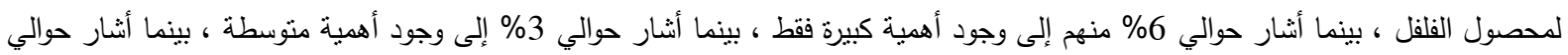

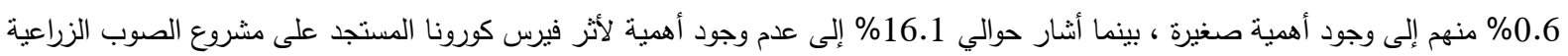

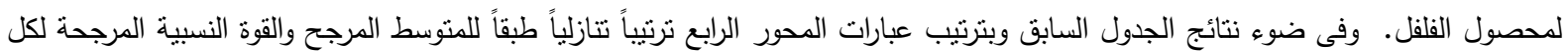

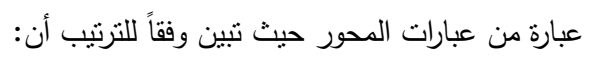

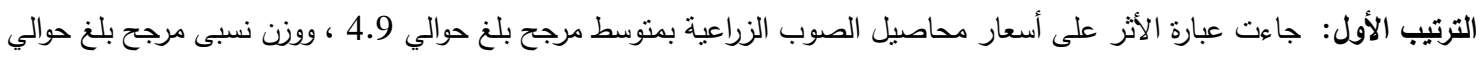

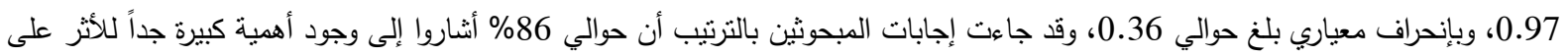

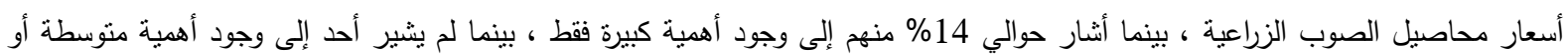

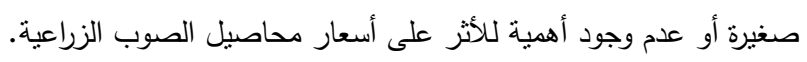

\begin{tabular}{|c|c|c|c|c|c|c|c|c|c|c|c|}
\hline 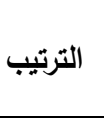 & النتيجة & المرجحة & الالمعياري & المتوسط & لديس له & 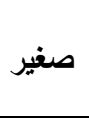 & متوسط & كبيز & كبير & & 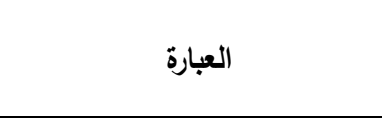 \\
\hline \multirow{2}{*}{5} & كبيز & \multirow{2}{*}{0.94} & \multirow{2}{*}{0.94} & \multirow{2}{*}{4.7} & 1 & 1 & $\mathbf{0}$ & 2 & 24 & تكرار & 1-الأثر على إنتاج الصوب \\
\hline & جداً & & & & 4 & 4 & 0 & 7 & 86 & $\%$ & الزراعية \\
\hline \multirow{2}{*}{2} & كبير & \multirow{2}{*}{0.96} & \multirow{2}{*}{0.79} & \multirow{2}{*}{4.8} & 1 & $\mathbf{0}$ & $\mathbf{0}$ & 2 & 25 & تكرار & 2-الأثر على تسويق منتجات \\
\hline & جداً & & & & 4 & 0 & 0 & 7 & 89 & $\%$ & الصوب الزراعية \\
\hline \multirow{2}{*}{4} & كبيز & \multirow{2}{*}{0.94} & \multirow{2}{*}{0.85} & \multirow{2}{*}{4.7} & 1 & $\mathbf{0}$ & 1 & 2 & 24 & 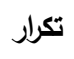 & \multirow{2}{*}{ 3-الأثر على هامش الريح } \\
\hline & جداً & & & & 4 & 0 & 4 & 7 & 86 & $\%$ & \\
\hline \multirow{2}{*}{1} & كبيز & \multirow{2}{*}{0.97} & \multirow{2}{*}{0.36} & \multirow{2}{*}{4.9} & $\mathbf{0}$ & $\mathbf{0}$ & $\mathbf{0}$ & 4 & 24 & تكرار & 4-الأثر على أسعار محاصيل \\
\hline & جداً & & & & 0 & 0 & 0 & 14 & 86 & $\%$ & الصوب الزراعية \\
\hline \multirow{2}{*}{3} & كبير & \multirow{2}{*}{0.94} & \multirow{2}{*}{0.71} & \multirow{2}{*}{4.7} & $\mathbf{0}$ & $\mathbf{0}$ & 4 & $\mathbf{0}$ & 24 & تكرار & 5-الأثر على توفر العمالة \\
\hline & جداً & & & & 0 & 0 & 14 & 0 & 86 & $\%$ & الزراعية المدرية \\
\hline \multirow{4}{*}{6} & ليس له & \multirow{2}{*}{0.31} & \multirow{2}{*}{1.43} & \multirow{2}{*}{1.6} & 24 & $\mathbf{0}$ & $\mathbf{0}$ & $\mathbf{0}$ & 4 & تكرار & 6-الأثر على تصدير محاصيل \\
\hline & 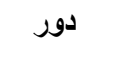 & & & & 86 & 0 & 0 & 0 & 14 & $\%$ & الصوب الزراعية \\
\hline & كبير & \multirow[t]{2}{*}{0.84} & \multirow[t]{2}{*}{0.43} & \multirow[t]{2}{*}{4.2} & 27 & 1 & 5 & 10 & 125 & تكرار & 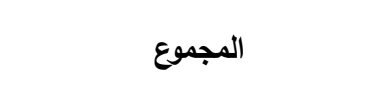 \\
\hline & & & & & 16.1 & 0.6 & 3.0 & 6.0 & 74.4 & $\%$ & النسبة المئوية \\
\hline
\end{tabular}

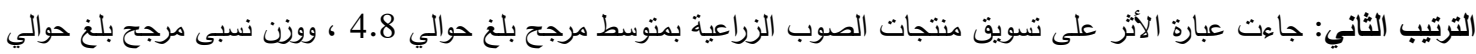

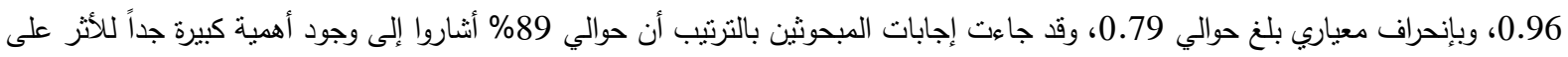

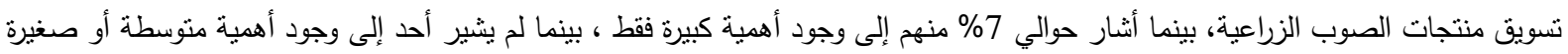

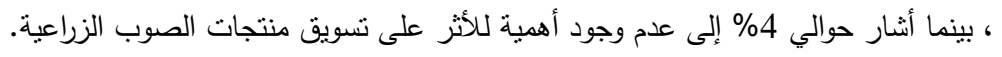

جدول رقم 8. أثر فيرس كورونا المستجد على مشروع الصوب الزراعية لمحصول الفلفل بعينة الدراسة بمحافظة الدقهلية 
الترتيب الثالث: جاءت عبارة الأثر على توفر العمالة الزراعية الددربة بمتوسط مرجح بلغ حوالي 4.7 ، ووزن نسبى مرجح بلغ حوالي

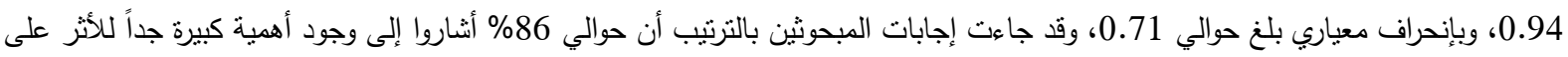

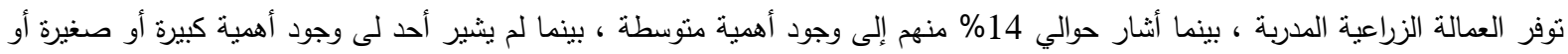
عدم وجود أهمية للأثر على توفر العمالة الزراعية المدربة.

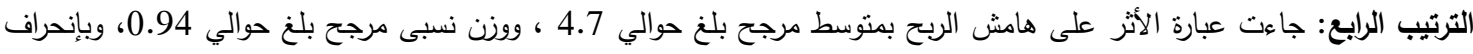

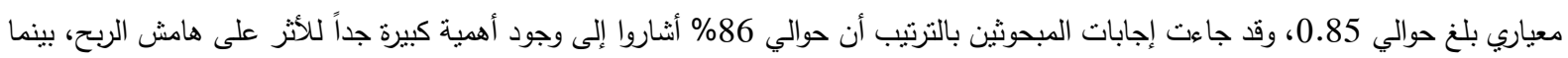

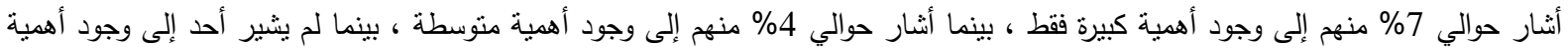

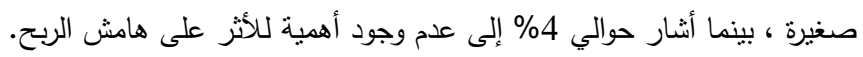

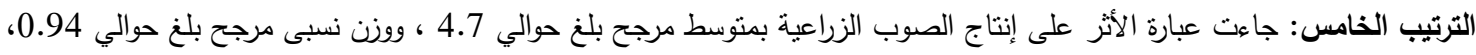

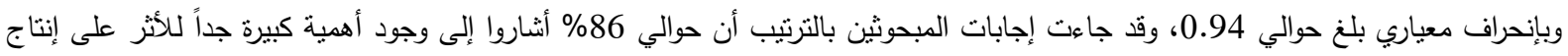

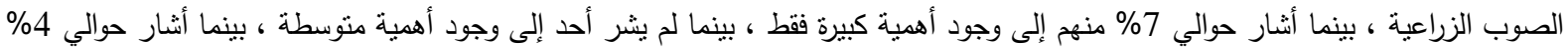

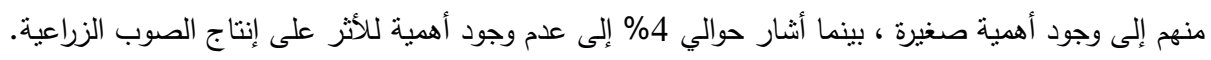

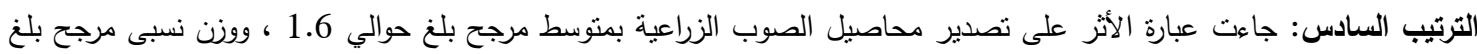

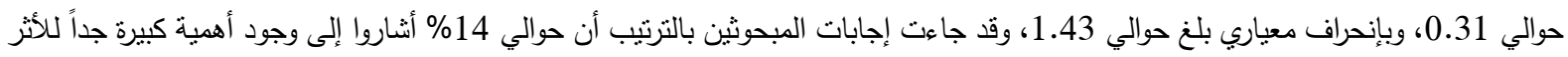

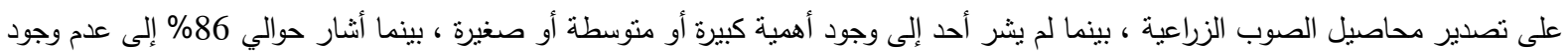
أهمية للأثر على تصدير محاصيل الصوب الزراعية.

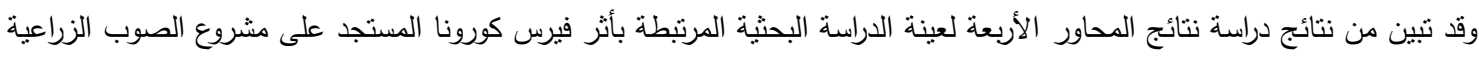

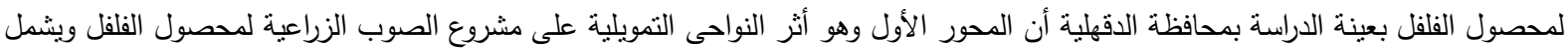

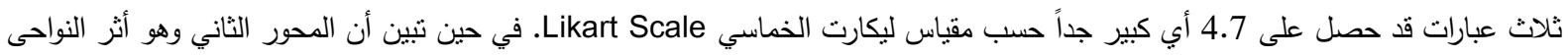

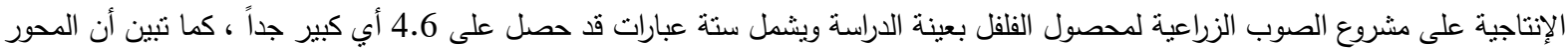

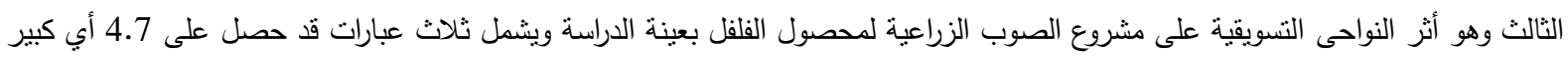

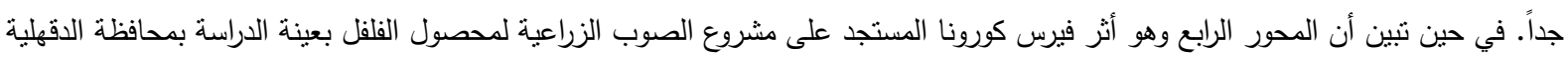
ويشمل ستة عبارات قد حصل على نـ 4.2 أي كبير جداً حسب مقياس ليكارت الخماسي.

ثالثاً :دراسة أهم العوامل المؤثرة على أثر فيرس كورونا المستجد على مشروع الصوب الزراعية لمحصول الفلفل بعينة الدراسة بمحافظة الدقهلية

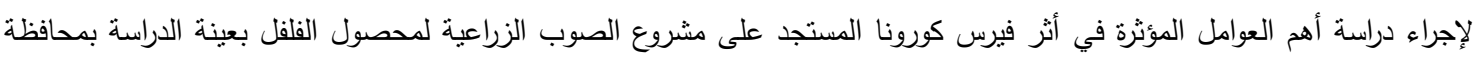

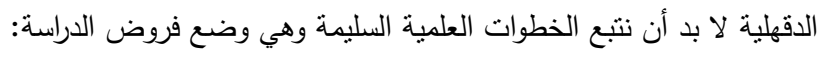
فروض العدم (الفروض الصفرية)

1- لا يوجد علاقة ذات دلالة إحصائية عند مستوى ثقة 95 \% بين أثر النواحى التمويلية على مشروع الصوب الزراعية لمحصول الفلفل بعينة

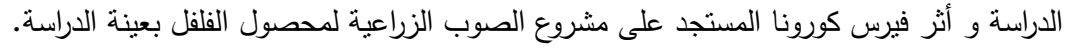

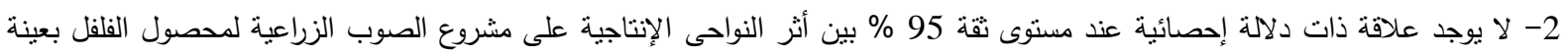
الدراسة و أثثر فيرس كورونا المستجد على مشروع الصوب الزئل الزراعية لمحصول الفلفل بعينة الدراسة.

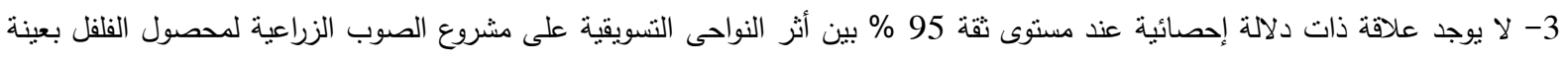
الدراسة و أثر فيرس كورونا المستجد على مشروع الصوب الزاتلة الزراعية لمحصول الفلفل بعينة الدراسة.

الفروض البديلة

1- يوجد علاقة ذات دلالة إحصائية عند مستوى ثقة 95 \% بين أثز النواحى التمويلية على مشروع الصوب الزراعية لدحصول الفلفل بعينة الدراسة

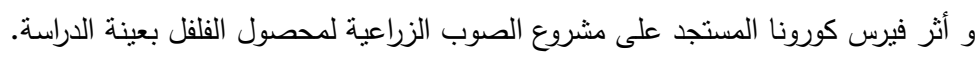

2- يوجد علاقة ذات دلالة إحصائية عند مستوى ثقة 95 \% بين أثن النواحى الإنتاجية على مشروع الصوب الزراعية لمحصول الفلفل بعينة الدراسة

و أثر فيرس كورونا المستجد على مشروع الصوب الزراعية لمحصول الفلفل بعينة الدراسة.

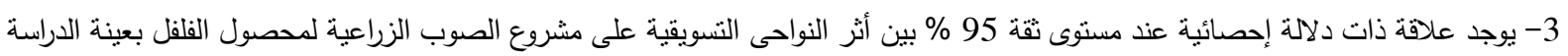

و أثر فيرس كورونا المتتجد على مشروع الصوب الزراعية لمحصول الفلفل بعينة الدراسة. 
جدول رقم 9 ـ نتائج الاندار المتعدد لمعرفة أثر المتغيرات المستقلة على أثر فيرس كورونا المستجد على مشروع الصوب الزراعية لمحصول الفقلل بعينة الدراسة بمحافظة الدقهلية

\begin{tabular}{|c|c|c|c|c|}
\hline مستوى الدلالة & قيمة ت & معامل الانحدار & المتغير & \\
\hline 0.567 & 0.58 & 0.633 & & ثابت الدالة \\
\hline 0.049 & 2.07 & 0.302 & & أثر النواحى التمويلية \\
\hline \multirow[t]{3}{*}{0.001} & 3.86 & 0.672 & & أثز النواحى التسويقية \\
\hline & 0.648 & & معامل التحديد & \\
\hline & $9.1^{* *}$ & & قيمة ف & \\
\hline
\end{tabular}

وقد تم تحديد المتغيرات المستقلة والتابعة، حيث تمثلت المتغيرات المستقلة في المحاور الأول (النواحى التمويلية) والثانى (النواحى الإنتاجية)

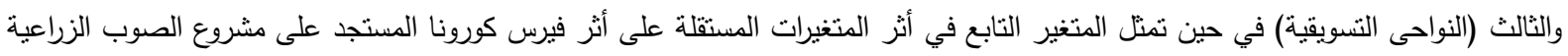

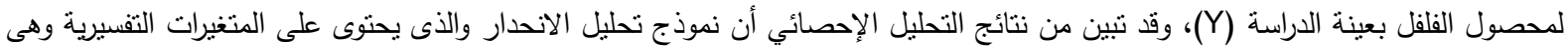

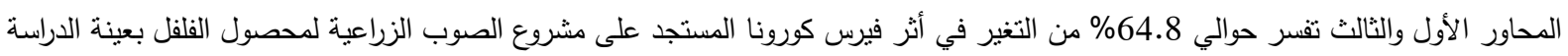

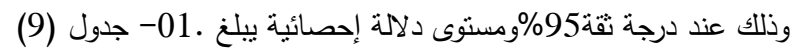

نتائج اختبار الفروض:

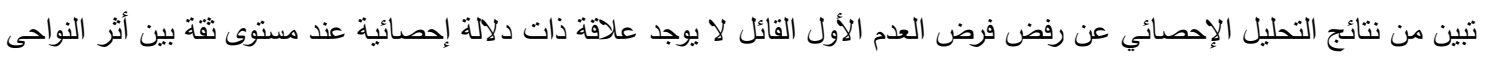

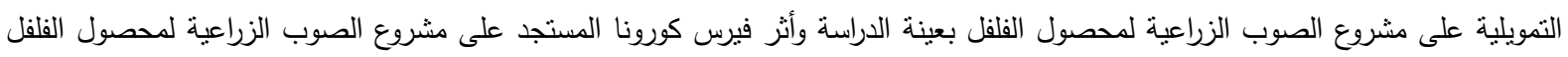

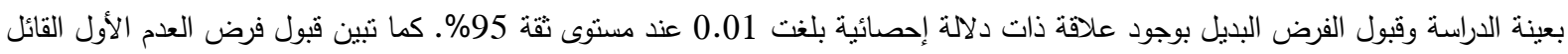

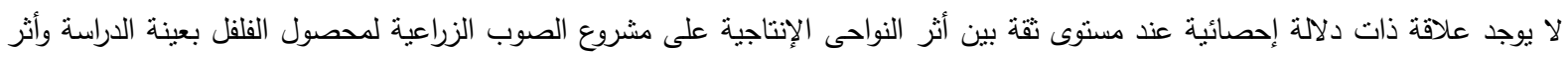

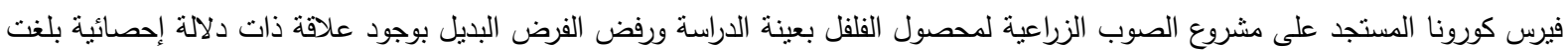

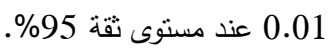

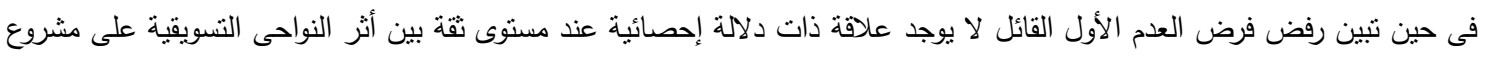

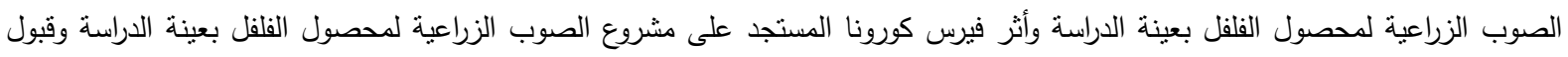

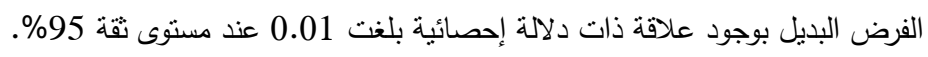

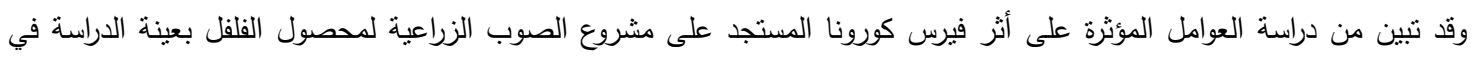

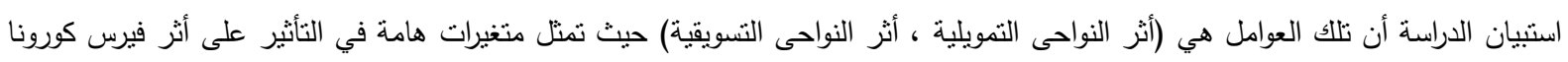
المستجد على مشروع الصوب الزراعية لمحصول الفلفل بعينة الدراسة.

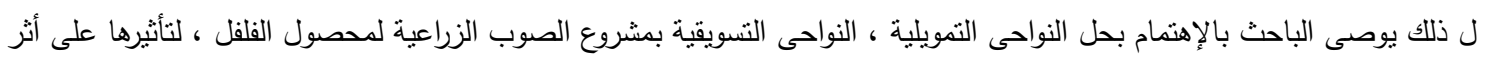

فيرس كورونا المستجد على مشروع الصوب الزراعية لمحصول الفلفل بعينة الدراسة.

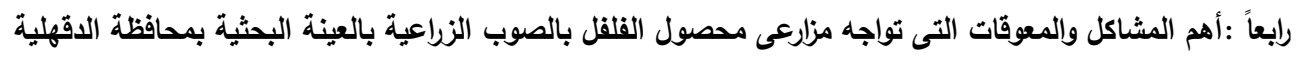

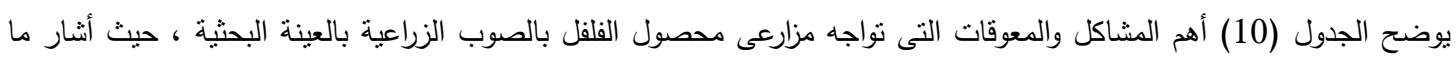

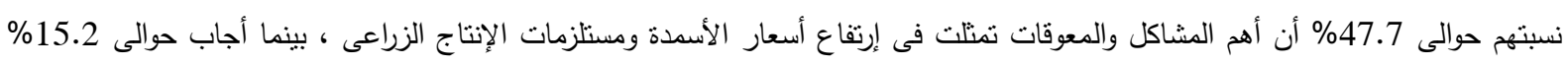

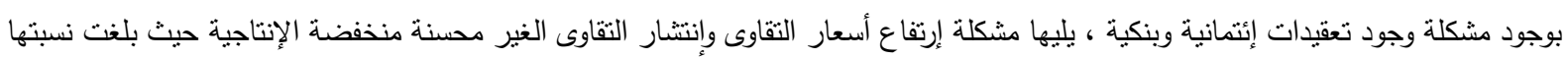

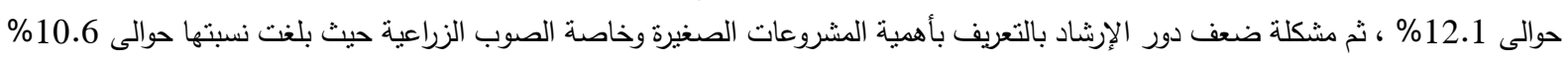

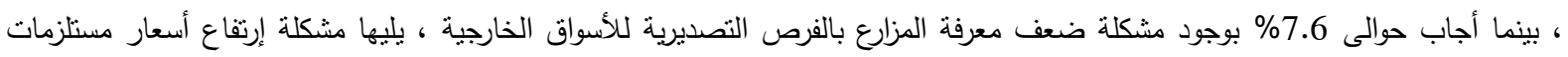

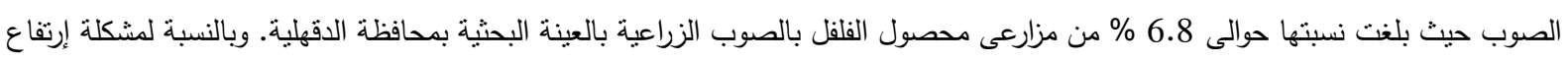

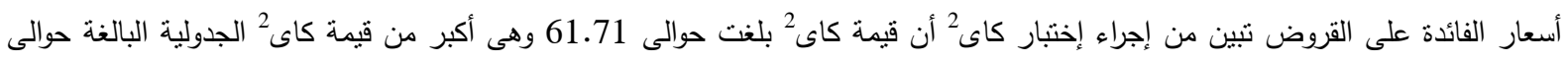

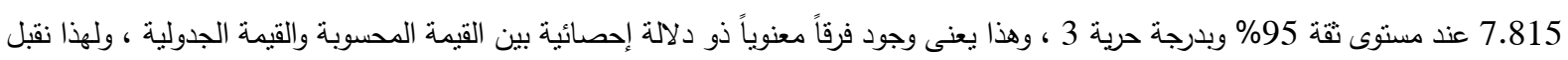

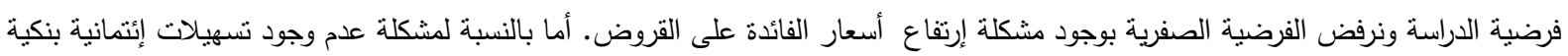

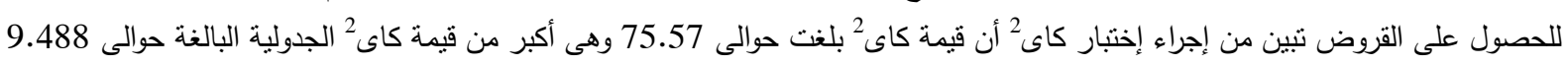


عند مستوى ثقة 95\% وبدرجة حرية 4 ، وهذا يعنى وجود فرقاً معنوياً ذو دلالة إحصائية بين القيمة المحسوبة والقيمة الجدولية ، ولهذا نقبل فرضية

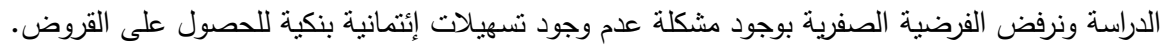

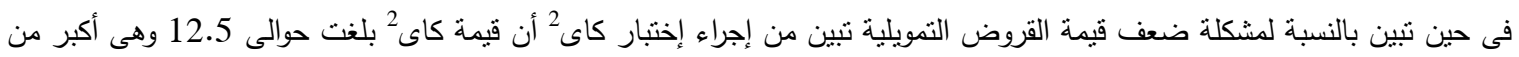
قيمة كاى2 الجدولية البالغة حوالى 5.991 عند مستوى ثقة 95\% وبدرجة حرية 2 ، وهذا يعنى وجود فرقاً معنوياً ذو دلالة إحصائية بين القيمة المحسوبة والقيمة الجدولية ، ولهذا نقبل فرضية الدراسة ونرفض الفرضية الصفرية بوجود مثكلة ضعف قيمة القية القروض التمويلية. كما تبين بالنسبة

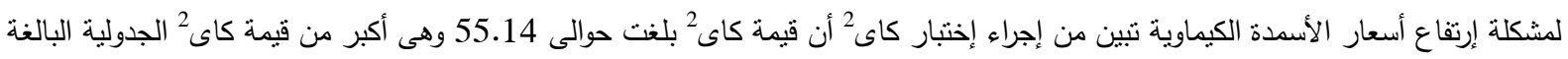

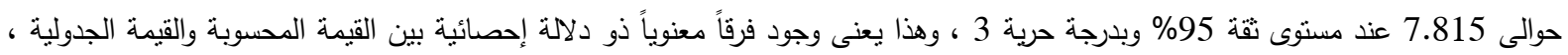
ولهذا نقبل فرضية الدراسة ونرفض الفرضية الصفرية بوجود مثكلة إرتفاع أسعار الأسمدة الكيماوية.أما بالنسبة لهشكلة إرتفاع أسعار المبيدات

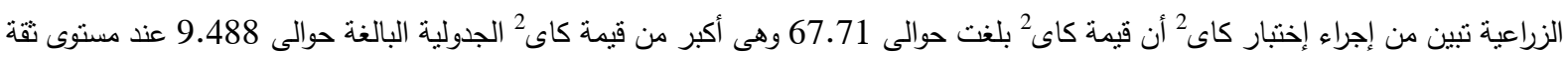

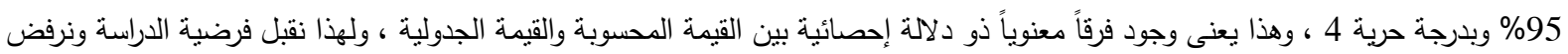
الفرضية الصفرية بوجود مشكلة إرتفاع أسعار المبيدات الزراعية.

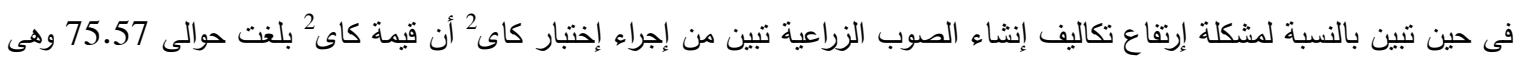

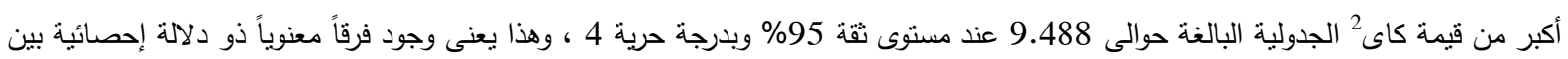

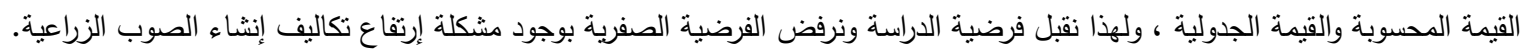

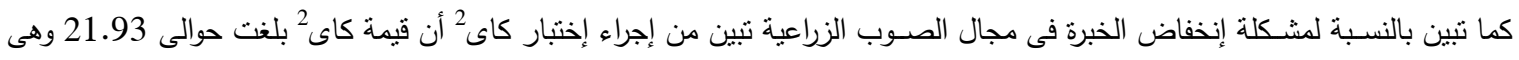

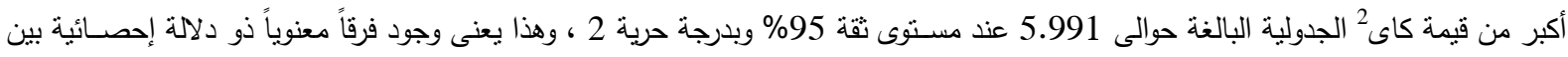

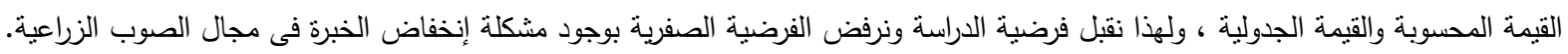

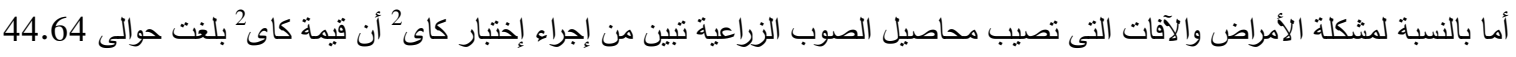

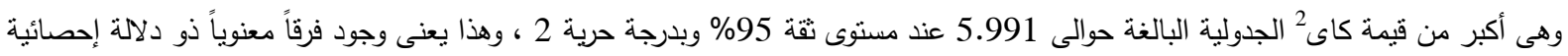
بين القيمة الدحسوبة والقيمة الجدولية ، ولهذا نقبل فرضية الدراسة ونرفض الفرالية الفية الفية الصفرية بوجود مشكلة الأمراض والآفات التى تصيب محاصيل الصوب الزراعية.

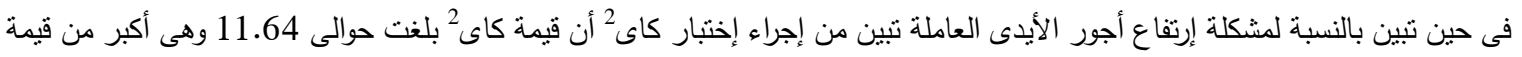

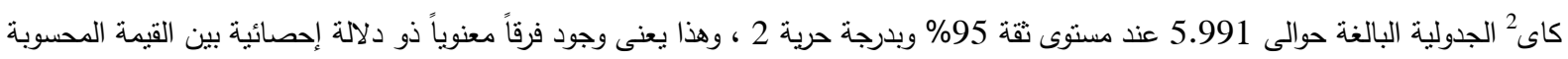

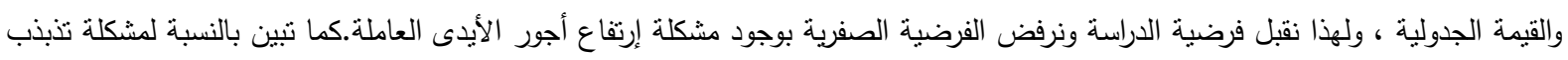

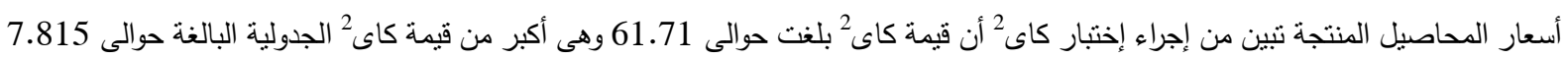

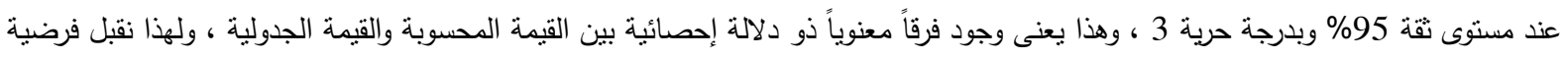

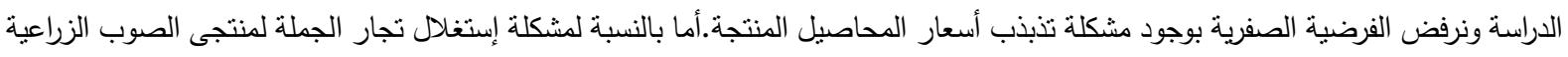

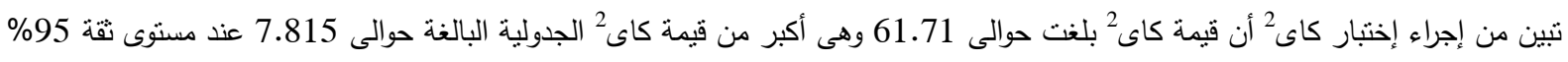

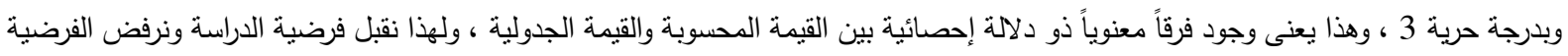

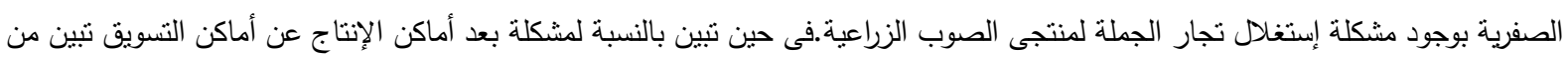

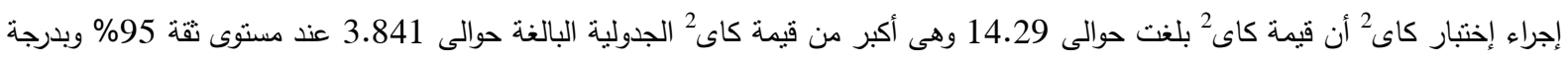

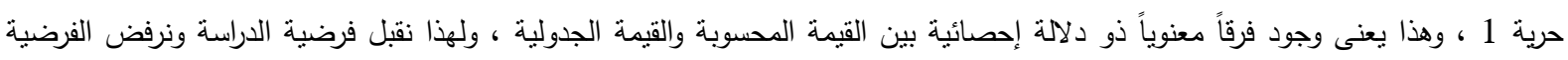
الصفرية بوجود مشكلة بعد أماكن الإنتاج عن أماكن النسويق.

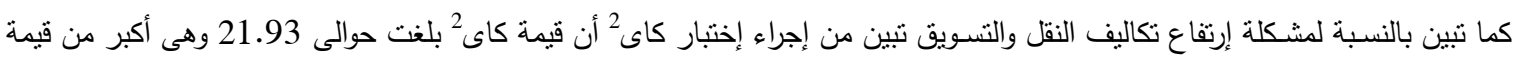

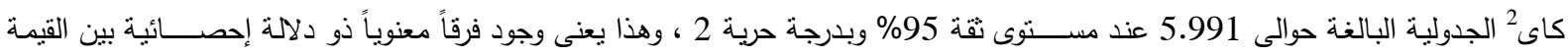

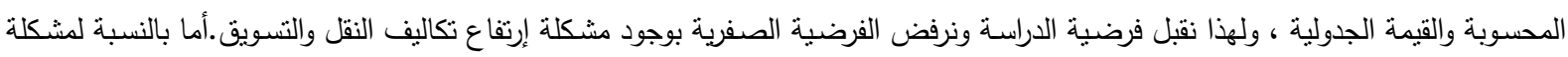

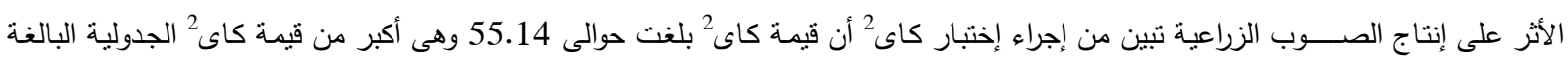

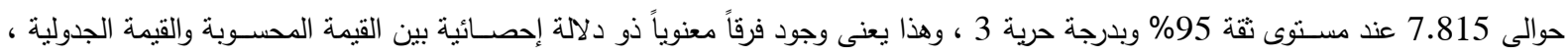

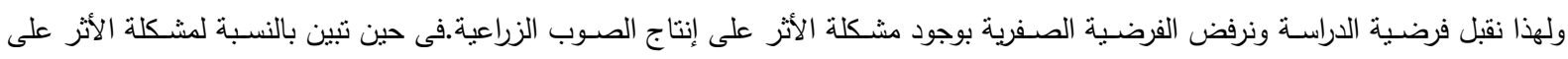

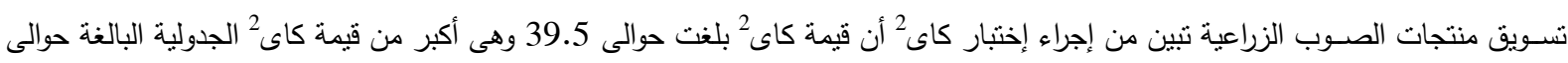

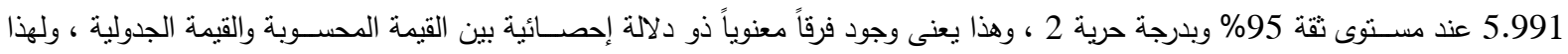

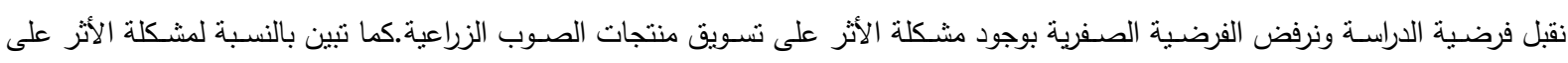




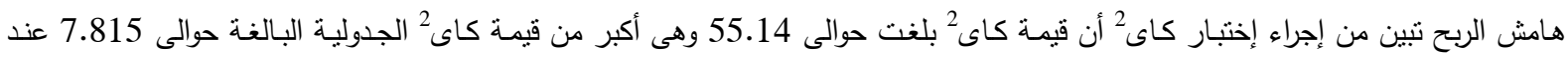

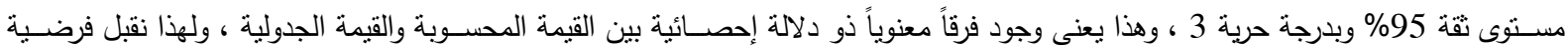

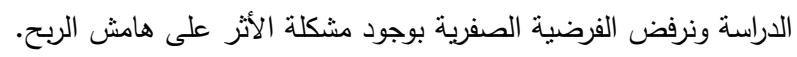

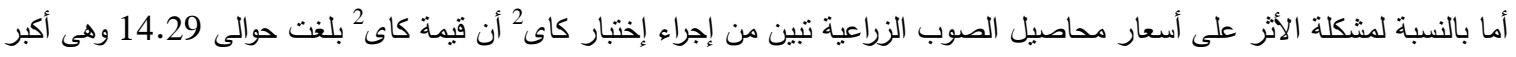

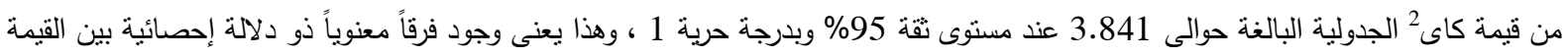

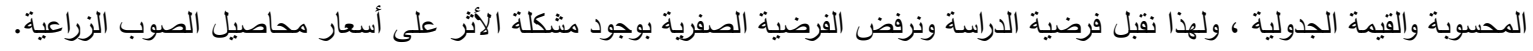

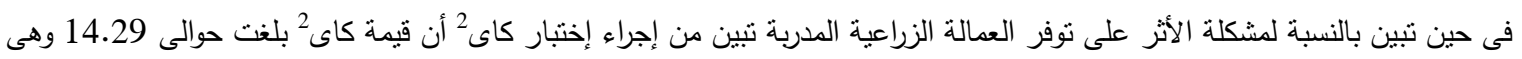

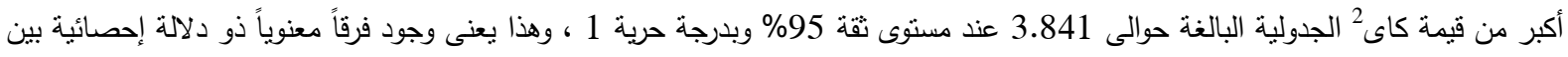

القيمة المحسوبة والقيمة الجدولية ، ولهذا نقبل فرضية الدراسة ونرفض الئل الفئل الفرضية الصفرية بوجود مشكلة الأثر على توفر العمالة الزراعية المدربة.

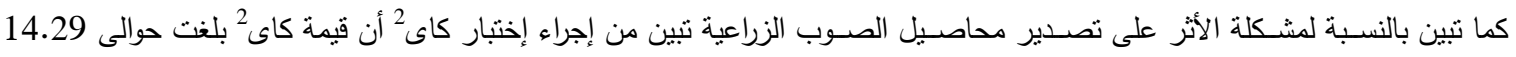

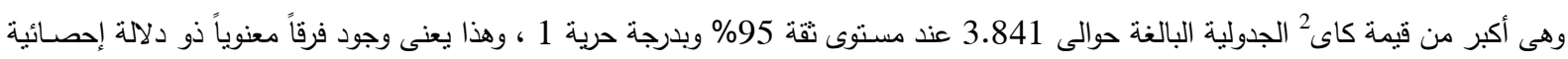
بين القيمة الحسوبة والقيمة الجدولية ، ولهذا نقبل فرضية الدراسة ونرفض الفرضية الصفية الصفرية بوجود مشكلة الأثر على تصدير محاصيل الصوب الزراعية. جدول 10 ـ نتائج تحليل مريع كاى لأهم المشاكل التى تواجه مزارعى محصول الفلقل بالصوب الزراعية بالعينة البحثية

\begin{tabular}{|c|c|c|c|c|}
\hline الجديمة القية & الحرية & الإحتمال & كاى 2 & 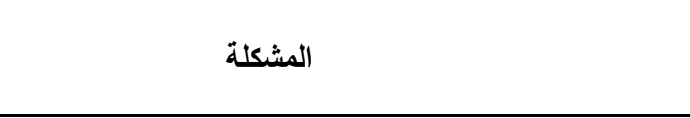 \\
\hline 7.815 & 3 & 0.000 & 61.71 & 1-إرتفاع أسعار الفائدة على القروض \\
\hline 9.488 & 4 & 0.000 & 75.57 & 2-عدم وجود تسهيلات إنتمانية بنكية للحصول على القروض \\
\hline 5.991 & 2 & 0.002 & 12.50 & 3-ضعف قيمة القروض التمويلية \\
\hline 7.815 & 3 & 0.000 & 55.14 & 1- إرتفاع أسعار الأسمدة الكيماوية \\
\hline 9.488 & 4 & 0.000 & 67.71 & 2- إرتفاع أسعار المبيدات الزراعية \\
\hline 9.488 & 4 & 0.000 & 75.57 & 3- إرتفاع تكاليف إنثاء الصوب الزراعية \\
\hline 5.991 & 2 & 0.000 & 21.93 & 4- إنخفاض الخبرة فى مجال الصوب الزراعية \\
\hline 5.991 & 2 & 0.000 & 44.64 & 5- الأمراض والآفات التى تصيب محاصيل الصوب الزراعية \\
\hline 5.991 & 2 & 0.003 & 11.64 & 6- إرتفاع أجور الأيدى العاملة \\
\hline 7.815 & 3 & 0.000 & 61.71 & 1-تذبذب أسعار المحاصيل المنتجة \\
\hline 7.815 & 3 & 0.000 & 61.71 & 2-إستغلال تجار الجملة لمنتجى الصوب الزراعية \\
\hline 3.841 & 1 & 0.000 & 14.29 & 3-بعد أماكن الإنتاج عن أماكن التسويق \\
\hline 5.991 & 2 & 0.000 & 21.93 & 4-إرتفاع تكاليف النقل والتسويق \\
\hline 7.815 & 3 & 0.000 & 55.14 & 1-الأثر على إنتاج الصوب الزراعية \\
\hline 5.991 & 2 & 0.000 & 39.50 & 2-الأثر على تسويق منتجات الصوب الزراعية \\
\hline 7.815 & 3 & 0.000 & 55.14 & 3-الأثر على هامش الريح \\
\hline 3.841 & 1 & 0.000 & 14.29 & 4-الأثر على أسعار محاصيل الصوب الزراعية \\
\hline 3.841 & 1 & 0.000 & 14.29 & 5-الأثر على توفر العمالة الزراعية المدرية \\
\hline 3.841 & 1 & 0.000 & 14.29 & 6-الأثر على تصدير محاصيل الصوب الزراعية \\
\hline
\end{tabular}

خامساً : أهم المقترحات من وجهة نظر مزارعى الصوب الزراعية لمحصول الفلقل بعينة الدارسة بمحافظة الدقهلية:

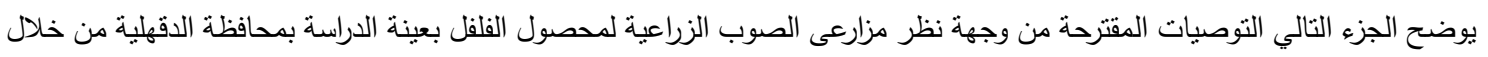

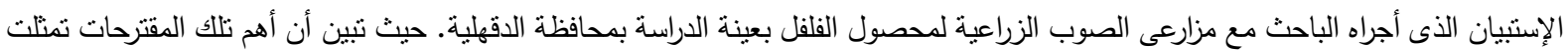


في خفض أسعار الأسمدة ومستلزمات الإنتاج الزراعى حيث متلت حوالى 47.7\%، يليها عمل تسعيلات إئمانية وبنكية بحوالى 15.2\%، يليها خفض أسعار التقاوى ونثر التقاوى المحسنة مرتفعة الإنتاجية بحوالى 12.1\%، يليها زيادة دور الإرشاد بالتعريف بأهمية المشروعات الصغيرة

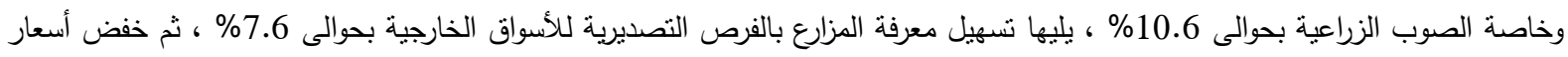

مستلزمات الصوب بحوالى 6.8\% - جدول رقم (11).

جدول رقم 11 ـ. التوصيات المقترحة من وجهة نظر مزارعى الصوب الزراعية لمحصول الفلفل بعينة الدراسة بمحافظة الدقهية

\begin{tabular}{|c|c|c|}
\hline$\%$ & 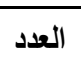 & التوصية \\
\hline 47.7 & 63 & خفض أسعار الأسمدة ومستلزمات الإنتاج الزراعى \\
\hline 15.2 & 20 & عمل تسهيلات إئتمانية وينكية \\
\hline 12.1 & 16 & خفض أسعار التقاوى ونثر التقاوى المحسنة مرتفعة الإنتاجية \\
\hline 10.6 & 14 & زيادة دور الإرشاد بالتعريف بأهمية المشروعات الصغيرة وخاصة الصوب الزراعية \\
\hline 7.6 & 10 & تسهيل معرفة المزارع بالفرص التصديرية للأسواق الخارجية \\
\hline 6.8 & 9 & خفض أسعار مستلزمات الصوب \\
\hline 100 & 132 & الإجمالى \\
\hline
\end{tabular}

ومن خلال النتائج التي توصل إليها البحث أمكن إقتراح بعض التوصيات لزيادة إنتاج الصوب من محصول الفلفل بالصوب الزراعية بعينة الدراسة بمحافظة الدقهلية

1- زيادة عدد النبانات في الصوبة الزراعية للوصول للسعة المزرعية المنلى لإنتاج محصول الفلفل.

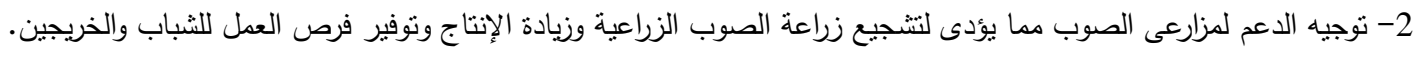
3-الإهتمام بنسويق محصول الخيار وزيادة نصيب المزارع من سعر المستهلك، من خلال خفض التكاليف الإنتاجية والتسويقية. 4-إجراء دراسات مماتلة لمحصول الخيار بالصوب الزراعية للتعرف علي أفضل أنواع المحصول الذئى يحقق إقتصاد السعة. 5-خفض أسعار والتقاوى الأسمدة ومستلزمات الإنتاج الزراعى ونشر التقاوى المحسنة مرتفعة الإنتاجية لتشجيع المزارعين. 6-عمل تسهيلات إئتمانية وبنكية لنتجيع الثباب والخريجين .

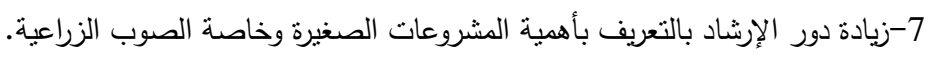
8-نسهيل معرفة مزارعى الصوب الزراعية بالفرص التصديرية للأسواق الخارجية . 9-خفض أسعار مستلزمات إنشاء الصوب الزراعية مما يقلل من التكاليف الإنثائية ويحث المستثر على الإستثمار فى تلك المشاريع.

1 الموقع الإلكترونى للجهاز المركزى للتعبئة العامة والآحصاء

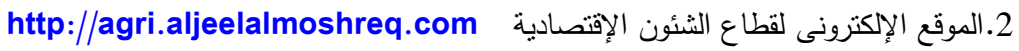

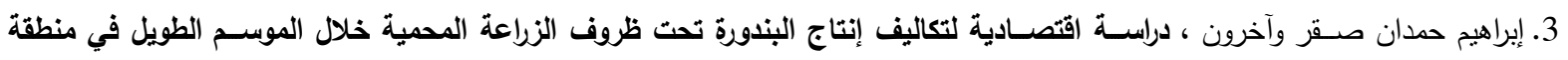

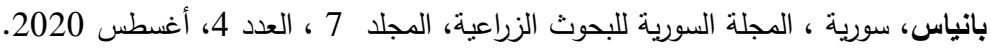
4. أميمة ممدوح وآخرون ، دراسـة اقتصادية لإنتاج الصوب الزراعية فى محافظة الفيوم ، قسم الاقتصاد الزراعي، كلية الزراعة، جامعة الفيوم، .2015 5. سمير عطية محمد عرام، إبراهيم حسن إبراهيم ، دراسـة اقتصادية تحليلية لإنتاج أهم محاصيل الخضر بالبيوت المحمية بمحافظة الثرقية،

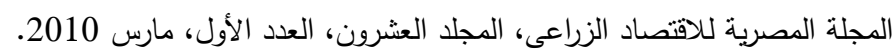

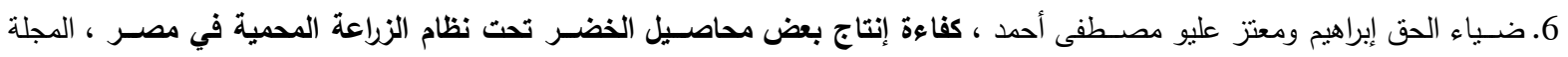

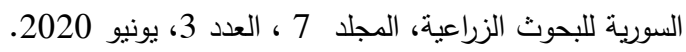
7. على عبد الدحن على ، كمال صالح عبد الحميد الدالى ، دراسة إقتصادية لأثر الصوب الزئراعية على كفاءة إستخدام موردى الأرض و مياه

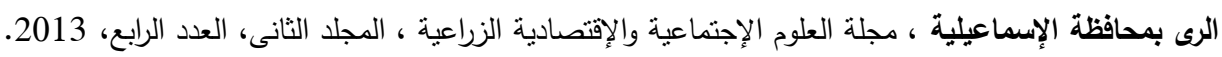




$$
\begin{aligned}
& \text { 8. لبنى محمد صـفوت الجارحى ومحمد رمضــان إسـماعيل، دراســة اقتصـادية لإنتاج الفاصـوليا الخضـراء بالصـوب الزراعية ، مجلة جامعة } \\
& \text { الزقازيق،المجلا الثالث والعشرون، العدد الثالث، ، } \\
& \text { 9. منير العجيزي، اقتصاديات إنتاج الخيار تحت الصوب الزراعية، المجلة المصرية للاقتصاد الزراعي،المجلد } 5 \text { ، العدد 1، مارس } 1995 . \\
& \text { 10. مها عبد الفتاح إبراهيم سيد ومنار عزت محمد بيومي، دراسـة اقتصـادية لأثر اسـتخدام الصسوب الزراعية على كفاءة اسـتخدام بعض الموارد } \\
& \text { الزراعية في مصر ، مجلة أسيوط للعلوم الزراعية،المجلد الخمسون، العدد الأول، رقم التسلسل الدولى } \\
& \text { 11. ممدوح البدرى محمد ، كفاعة ومشـاكل إسـتخدام الأســدة الكيماوية لبعض المحاصسيل الزراعية في مركز كفر الدوار بمحافظة البحيرة، مجلة }
\end{aligned}
$$

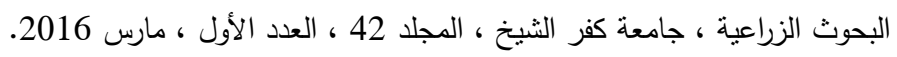

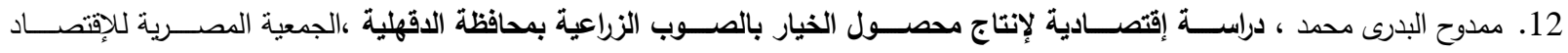

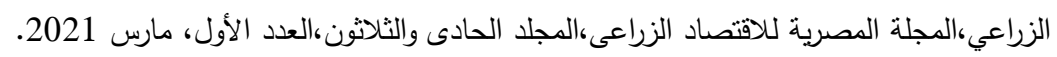

$$
\begin{aligned}
& \text { 13. ممدوح البدرى محمد ، دراسـة إقتصادية لأهم المشـاكل والمعوقات التى تواجه مزارعى محصول الخيار بالصوب الزراعية بمحافظة الدقهلية فى في }
\end{aligned}
$$

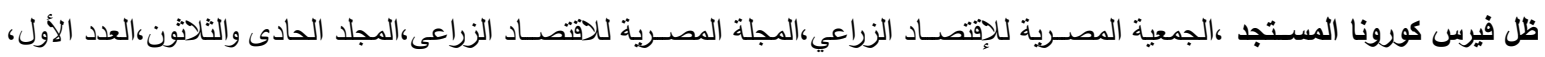

$$
\begin{aligned}
& \text { مارس } 2021 .
\end{aligned}
$$

14. Johnston, J., Econometric Methods, 3rd, McGraw-Hill Book Company, New York, 1984.

15. Mamdouh Elbadry and others ,An Economic Study of the Marketing Efficiency for the Most Important Crops and Agricultural Commodities in Egypt, Third International Conference on Advances in Social Science, Management and Human Behavior, Zurich, Switzerland ,2015.

\title{
An economic study for the Most Important Problems and Obstacles Facing the Green pepper Farmers in Agricultural Greenhouses in Dakahlia Governorate in light of Covid corona virus
}

\author{
Dr. Rasha Saleh Mansour \\ rashashalaan@gmail.com \\ Senior Researcher - Agricultural Economics Research Institute
}

\begin{abstract}
Greenhouse projects, especially those that grow vegetable crops, are considered among the most profitable projects, as these projects lead to bridging the gap between supply and demand of these crops, in addition to increasing farmers' income, which leads to raising the standard of living of farmers, and providing opportunities Work for young graduates, and those resulting crops can be exported to foreign markets, especially European markets, opening new markets for Egyptian agricultural exports, which leads to an increase in agricultural exports, reducing the deficit in the agricultural balance, and providing hard currency for the state. Despite the importance of greenhouse projects in increasing agricultural production, mitigating the seasonal phenomenon of agricultural production, reducing unemployment, and reducing the gap between supply and demand in agricultural crops resulting from greenhouses, whether in local markets or exporting them to foreign markets. Despite the high return results of growing vegetable crops in greenhouses, where the productivity of one acre of greenhouses increases six times what traditional agriculture produces of those crops, but these projects still suffer from some economic and productivity problems, which leads to poor spread.

The research relied on the descriptive statistical analysis method, the use of Cronbach's alpha coefficient to measure the validity and reliability of the research sample, and the chi-square test to analyze the problems of the research sample. The research was based on primary data, through questionnaires, which were collected from the farmers of the study crops in Dakahlia Governorate, during interviews with farmers. The research also relied on secondary data published on: The website of the Economic Affairs Sector, and some researches, theses, studies, and scientific books related to the topic of research were used.

The research aims at an economic study of the most important problems and obstacles facing Green pepper farmers in greenhouses in Dakahlia Governorate, in light of the Corona virus, through: (1) identifying the most important problems and obstacles facing Green pepper farmers in greenhouses and study the proposing appropriate solutions to them. (2) Identifying the impact of the Corona virus on the greenhouse project for the Green pepper crop by study sample. (3) Studying the most important factors affecting the Corona virus, on the greenhouse project for the Green pepper crop by study sample. It was found that the most important factors affecting the Corona virus, to the project of planting Green pepper crop in greenhouses in study sample, are the financing problems, marketing problems, as they represent important variables in influencing, the Corona virus on, the project of planting the Green pepper crop in greenhouses, so The researcher recommends paying attention to solving the financing and marketing problems of their impact on the project of cultivating the Green pepper crop in greenhouses, in the research sample in Dakahlia Governorate.
\end{abstract}

